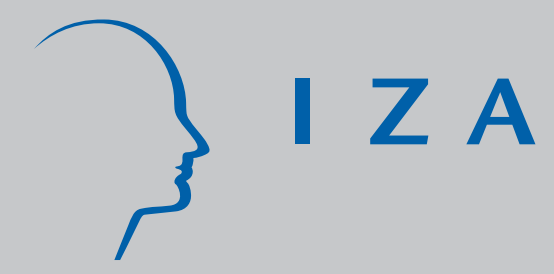

IZA DP No. 1600

Migration, Co-ordination Failures and EU Enlargement

Tito Boeri

Herbert Brücker

May 2005 


\title{
Migration, Co-ordination Failures and EU Enlargement
}

\author{
Tito Boeri \\ Bocconi University Milan, IGIER \\ and IZA Bonn \\ Herbert Brücker \\ DIW Berlin, Aarhus School of Business \\ and IZA Bonn \\ Discussion Paper No. 1600 \\ May 2005
}

IZA
P.O. Box 7240
53072 Bonn
Germany

Phone: +49-228-3894-0

Fax: +49-228-3894-180

Email: iza@iza.org

\begin{abstract}
Any opinions expressed here are those of the author(s) and not those of the institute. Research disseminated by IZA may include views on policy, but the institute itself takes no institutional policy positions.

The Institute for the Study of Labor (IZA) in Bonn is a local and virtual international research center and a place of communication between science, politics and business. IZA is an independent nonprofit company supported by Deutsche Post World Net. The center is associated with the University of Bonn and offers a stimulating research environment through its research networks, research support, and visitors and doctoral programs. IZA engages in (i) original and internationally competitive research in all fields of labor economics, (ii) development of policy concepts, and (iii) dissemination of research results and concepts to the interested public.
\end{abstract}

IZA Discussion Papers often represent preliminary work and are circulated to encourage discussion. Citation of such a paper should account for its provisional character. A revised version may be available directly from the author. 


\begin{abstract}
Migration, Co-ordination Failures and EU Enlargement*

European migration policies are characterised by a fundamental paradox: they are getting tighter and tighter just while public opinion is becoming more favourable to migrants and the immobility of European citizens expands the scope for spatial arbitrage, accruing the benefits, of immigration. In this paper we consider two possible explanations for this puzzle. At first, based on a computable general equilibrium model, we evaluate whether migration to "rigid labour markets" a-la European involves cost, which are neglected by economic theory. Our results suggest that the economic benefits from international migration are, at a GDP gain of $0.2-0.3 \%$ at a migration of $1 \%$ of the labour force, but that natives in the receiving countries may lose out especially when generous unemployment benefits are provided to the migrants. Then, we evaluate effects of co-ordination failures in the setting of national migration policies, documenting that a race-to-the-top in migration restrictions has indeed occurred in the case of the Eastern Enlargement of the EU and has involved significant diversion of migration from more restrictive to less restrictive countries. Finally we discuss two potential ways to invert the trend towards stricter barriers to migration, namely i) restricting access to welfare and ii) adopting an EU-wide migration policy.
\end{abstract}

JEL Classification: J61, F16, F2

Keywords: migration, enlargement, welfare door

Corresponding author:

Tito Boeri

IGIER - Università Bocconi

Via Salasco 5

20136 Milano

Italy

Email: tito.boeri@uni-bocconi.it

\footnotetext{
* This paper was prepared for the Economic Policy Panel meeting in Luxembourg, 15/16th April 2005. The authors wish to thank Richard Baldwin and two anonymous referees for comments on an initial draft. They are also indebted to Paola Monti for skilful research assistance.
} 


\section{INTRODUCTION}

EU leaders are well aware of the relevance of migration in the European policy agenda. Thirty-two pages out of forty-eight of the Presidency Conclusions at the November 2004 European Council were devoted to migration policies. Economic theory suggests that there is a strong case for policy co-ordination in this field: relevant spillovers across national jurisdictions, economies of scale and potential free-riding in the enforcement of border controls. However, no delegation of authority to supra-national bodies is envisaged in the Presidency Conclusions in the field of restrictions to legal migration. While Qualified Majority Voting is now accepted on measures tackling illegal migration, decisions on restrictions to legal migration are envisaged only under unanimity rules.

Un-coordinated national policies are getting increasingly tough on migrants. Border controls are tightened or welfare access is prevented to foreigners or both doors, work and social assistance, are closed. This does not seem to prevent migration to occur. It distorts its geographical orientation, modifies its skill composition and inflates the ranks of the informal sector. Illegal migration is larger when restrictions to legal migration are tight. Illegal flows as a proportion of the population are about one fourth larger in Europe than in the US; at the same time, legal flows are 25\% larger in the US than in Europe. And the US has more realistic migration restrictions than most European countries.

Countries are getting tougher also because they fail to co-ordinate. The implications of the failure of policy co-ordination in terms of national restrictions came out very clearly with the Eastern Enlargement. There was a "race to the top" of migration restrictions with 12 out of the 15 Member States of the European Union (EU) reneging on their previous commitment not to restrict worker flows from the New Members. And the few EU-15 countries that ultimately opened their labour markets for workers from the New Member States at least partially restricted instead access to welfare by migrants. Lack of co-ordination raises concerns among public opinion that migration flows could be diverted to the most liberal countries, increasing pressures on their welfare systems. Diversion of migration flows is, by itself, undesirable on economic grounds. It means that migration cannot fully play a spatial arbitrage function, "greasing the wheels" of otherwise immobile labour markets.

Thus, national Governments seem to be caught into a vicious circle: they top-up migration restrictions enforced by other countries ending up for the most to increase illegal migration, which itself raises concerns among public opinion inducing a tough stance towards migrants.

Why is it so difficult to co-ordinate migration policies at the EU level? Is it because of free-riding? Who gains and who loses from uncoordinated migration restrictions? How much do they distort East-West migration both in terms of the geographical orientation of worker flows and the skill composition of migration? It may well be that the countries not located at the borders of the Union and hence receiving less migrants prefer to enjoy the benefits of stronger growth elsewhere in the Union without having to bear the assimilation and fiscal costs of immigration. Another explanation is that for non-economic reasons (e.g., historical and cultural factors) citizens of different EU 
countries have different views about migration and hence oppose any policy coordination at the EU level. Else it is national politicians who prefer to keep under their jurisdictions migration policies as they target a convenient political scapegoat, namely the non-voting immigrant.

The purpose of this paper is to shed some light on these issues, by drawing on lessons from the Eastern Enlargement episode, using preliminary evidence on migration to countries with different types of restrictions, predictions from a computable general equilibrium model as well as public opinion polls.

The plan is as follows. At first, in Section 1, we succinctly review recent evolutions of migration restrictions in the EU-15 and the "race to the top" occurred in the eve of the Eastern Enlargement. Moreover, we analyse whether and to what extent the transitional arrangements result in the diversion and reduction of East-West migration flows. For this purpose, we compare estimates of the migration potential with recent migration patterns observed after May 1, 2004. Next, in Section 2, we evaluate, based on a stylised general equilibrium model, not only the costs for the EU of having un-coordinated migration policies, but also potential explanations of the failure to co-ordinate policies. Although the potential income gains from East-West migration exceed those from the further integration of goods and capital markets, the uneven distribution of gains and losses across receiving and sending countries can create incentives for closing-the-door policies and for free-riding on liberal policies of other countries. Moreover, we analyse whether welfare benefits increase income in the region by facilitating further migration and whether the distribution of welfare benefits generates itself incentives for coordination failures. In Section 3, we turn to perceptions as to the costs and benefits of migration in general and from the East in particular, as revealed by public opinion polls in the West. We look at whether or not they point to a divergence of preferences on these issues and what are the determinants of cross-country difference in the degree of acceptance of migrants in relation with economic as well as non-economic factors. Finally, in Section 4 we summarise our results and draw implications as to ways to overcome resistance of some governments to co-ordinate policies.

\section{RECENT EVOLUTIONS IN NATIONAL IMMIGRATION POLICIES}

\subsection{The tightening of immigration restrictions}

International migration is the "great absentee" in the era of globalisation. While the barriers to international trade and capital mobility have already been largely removed, labour markets are the most tightly regulated area of economic activity (Faini et. al., 1999). Governments regulate, among other things, the maximum number of work permits to be granted within a given period of time (usually a year), the criteria to be followed in ranking applications for visas (e.g., skills, linguistic capabilities, nationality, family links), the duration of the work permits, the procedures to be followed in the renewal of visas, the number of years required before obtaining a permanent residence permit, the type of residence permits allowed (e.g., temporary vs. permanent), the nature and number of certificates and guarantees required for the admission in the host country, the type and number of administrations involved in the processing of applications, and the procedures to be followed in case of family reunification. Not less regulated is 
asylum seeking migration, which often respond also to economic factors. Regulations are also frequently revised, which increases the uncertainty associated with the decision to migrate. This may have perverse effects on the timing of migration - as there is an option value in migrating before borders are closed - but certainly increases its costs.

Within the European Union (EU) matters are, at least in principle, different. Since the Rome Treaty, which established the European Economic Community (EEC) in 1957, the free mobility of labour has been acknowledged as one of the four fundamental freedoms of the Common Market. Free movement started in a community of six countries with a joint population of 185 million people, and has been extended step-bystep to the 15 members of the 'old' EU and the three other members of the European Economic Association (EEA) with a joint population of 380 million people. Although many barriers to intra-EU mobility of EU citizens remain (e.g., in terms of portability of private pension rights, legal recognition of professions, information about job opportunities, etc.), the free mobility of labour, including the equal treatment with regard to welfare benefits, is in principle guaranteed by the supranational legislation of the EU.

Legal immigration into the EU from third countries is instead regulated at the national level and the recent evolution of these national migration policies in the EU involved tighter and tighter restrictions. Since 1996 there have been 35 reforms in this field, that is, almost 4 reforms per year. Most of these reforms (80\%) are marginal in that they adjust specific provisions rather than revising the overall regulatory framework. Furthermore, 7 reforms out of 10 tighten regulations, e.g., by increasing procedural obstacles faced by those applying for visas, reducing the duration of work permits or making family reunification more difficult. The trend in migration policies can also be characterised in terms of indexes for the main policy areas. Figure 2.1. draws on immigration policy indexes developed at Fondazione Rodolfo Debenedetti (see www.frdb.org for details) and an index of restrictions in asylum policies defined by Hatton (2004). Larger values of the indexes denote tighter regulations. As shown by Figure 2.1., it is mainly requirements to be fulfilled for being granted an entry visa and national quotas which are getting tighter. Some relaxation is occurring in terms of years required to obtain citizenship and assimilation policies are sometimes being strengthened, but entry is becoming more and more difficult.

Importantly, countries tightening regulations are often those which had the most restrictive provisions to start with. This is the visual impression given by Figure 2.2., plotting the value of the aggregate policy index obtained by taking the average of the six indicators displayed in Figure 2.1. in the initial and final year for which observations are available. Not only are most countries above the bisecting line through the origin, denoting a tightening of regulations, but also it is the countries which initially had the most liberal policies (perhaps because they were historically emigration countries) which have liberalised flows. 
Figure 2.1 Trends in Migration Policies

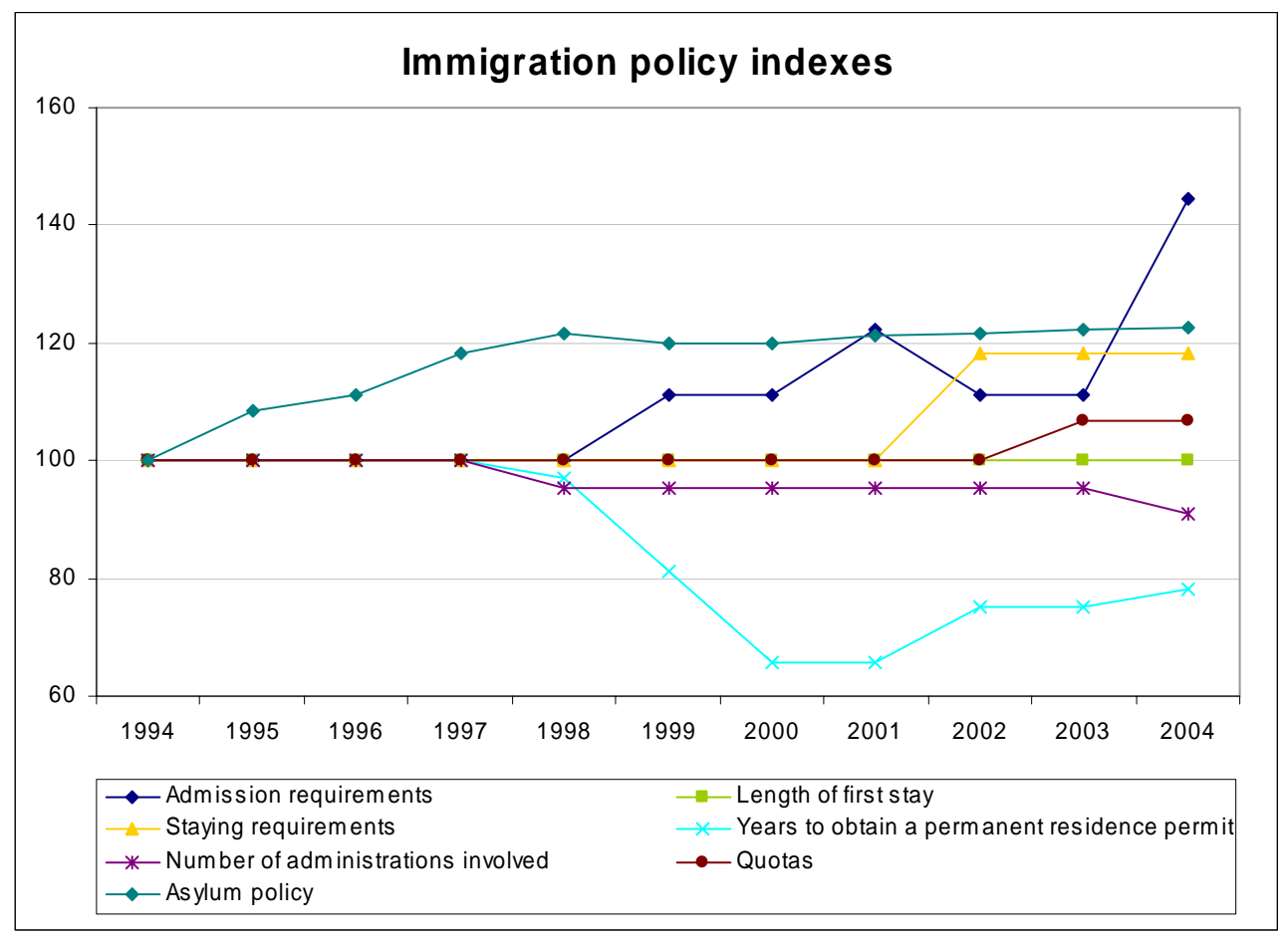

There is also evidence that reforms are exerting spillover effects across jurisdictions. For instance, Finland tightened up its regulations in 2004, following closely the most restrictive stance taken by Denmark in 2002. Portugal adopted more restrictive provisions in 2001, just after a likewise restrictive reform implemented by Spain in 2000. And Ireland chose a more restrictive approach in 1999, after two reforms in the UK, which tightened up migration restrictions, respectively in 1996 and 1998. Moreover, individual countries closely monitor developments in other countries. In the website of the British Home Office one can find several reports reviewing the evolution of migration policies in the other EU Members. Recently Denmark and the Netherlands protested against the large regularisation process in Spain, arguing that it could have pushed more illegal migrants into the EU. In the public debate, reference is often made to changes in migration policies occurred in other countries. The provocative proposal of the leader of the Italian Northern League, Umberto Bossi, to build-up a wall at the border of Italy with Slovenia was based on the fact that Austria was closing border towards migrants from the New Members states. And the current Danish Prime Minister has been actively campaigning on migration referring to policies carried out in Germany, UK and Sweden.

Policy spillovers are present also in the case of Asylum Policies, where a rush to the top occurred towards the end of the 1980s after the initial decision of Germany and, later, the UK to tighten asylum legislation (Hatton, 2004). In the case of policies for immigrations of highly skilled migrants, spillover are instead occurring in the other direction (OECD, 2001), with a race in trying to attract more highly skilled migrants. For instance, the decision of France in 2004 to introduce tax deductions for highly skilled migrants was explicitly motivated by the fact that Belgium had adopted policies encouraging inflows of highly skilled workers. Similarly., the British ad hoc scheme for 
highly skilled migrants was motivated referring to the measures being taken in Germany.

Figure 2.2. Convergence in immigration policies?

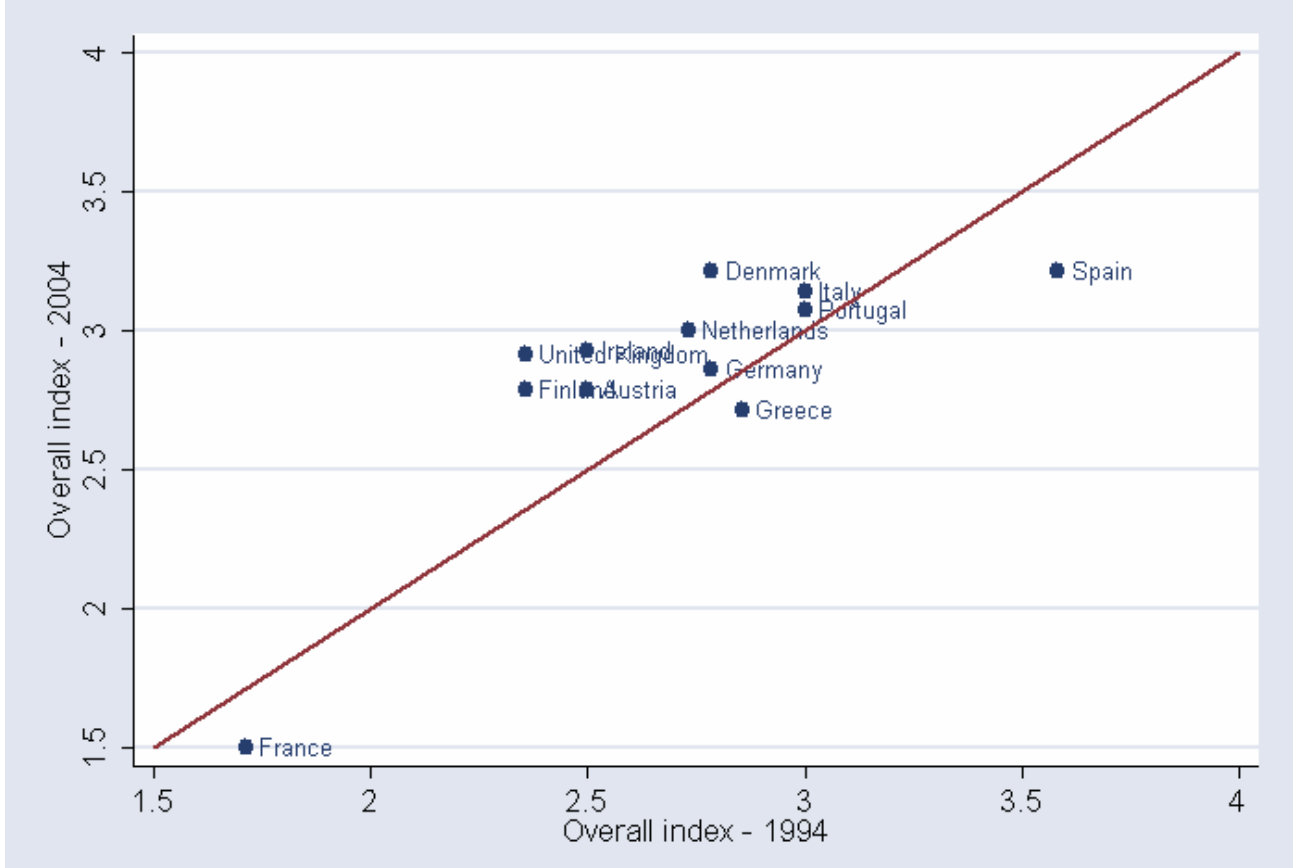

Spillovers in migration policies were also evident in the way in which the EU-15 adjusted their regulations on work permits in the eve of the Eastern Enlargement, exploiting the transitional arrangements allowed for by the accession treaties. This event is discussed below.

\subsection{Eastern Enlargement and the "Race-to-the-Top"}

Fifteen years ago, the 'iron curtain' was lifted for a region of approximately 400 million people in Central and Eastern Europe. Eight of these Central and Eastern European countries $^{2}$ joined the EU on the $1^{\text {st }}$ of May, 2004. Another two countries, Bulgaria and Romania, are expected to accede in 2006 or 2007. The joint population of the eight New Member States (NMS) from Central and Eastern Europe amounted to 72 millions in 2004, the population of the two other accession candidates number some 30 millions. The accession treaties contain transitional arrangements for the free labour mobility, which allow to postpone the opening of labour markets up to a maximum period of seven years. ${ }^{3}$ These transitional provisions can only be adopted sequentially: at first, in the two years following accession, all Member States can apply national rules on access to their labour markets; at the end of this two-year period, each Member State can choose to apply national rules for another three years or implement the Community rules regulating free labour mobility in the EU. If the countries decide to apply the

\footnotetext{
${ }^{2}$ Czech Republic, Estonia, Hungary, Latvia, Lithuania, Poland, Slovak Republic and Slovenia.

${ }^{3}$ Free movement is granted to the citizens from the new Member States in principle, but the EU countries can restrict the access to their labour markets during the transitional periods.
} 
Community rules, they maintain a safeguard clause meaning that they can reintroduce work permits temporarily. There will be an automatic review before the end of the twoyear period and a further review on request of each affected Member State, but the decision on the application of transitional periods is left to the national Governments. At the end of the five year period, Community rules should be introduced under normal circumstances, but the transitional periods can be prolonged for another two years if the Member State can document that it experiences (or is "threatened" by) 'serious disturbances' in its labour market. Again, the decision on the prolongation of the transitional periods is left to national Governments.

Transitional periods for the free mobility of labour have been agreed also in other Enlargement rounds: in case of the accession of Greece a six-year transitional period was agreed, and, at the accession of Portugal and Spain, a seven-year transitional period was introduced, later on reduced to six years. However, what makes the present rules different from those adopted in previous Enlargement rounds is that individual countries are let free to decide on whether or not adopting the transitional arrangements. Delegating the decision on transitional periods to the national level had important consequences: seven out of fifteen Member States of the EU, among them Austria and Germany, who attract about two-thirds of the migrants from the accession countries at present, declared from the beginning that they planned to leave relatively tight restrictions to the immigration of labour in place at least for the first two years after Enlargement. ${ }^{4}$ Governments of another five countries - Denmark, Ireland, the Netherlands, Sweden and the UK - stated instead that they planned not to restrict the access to their labour market at that time, while the remaining countries (Greece, Italy, Portugal and Spain) remained undecided although the relevant Ministers publicly stated that they were in favour of free mobility of workers from the NMS. The Governments in three out of the five countries which had formally stated their intention to open-up their labour market reneged on this commitment and all adopted transitional restrictions visà-vis workers from the NMS.

In particular, in Denmark, the government agreed with the opposition to concede a work permit only to those individuals from the new Member States who can prove that they have a job which meets regular standards with regard to wage and working conditions. If a migrant looses her job, residence permits are withdrawn (Danish Minister of Employment, 2004). The Netherlands reversed the decision of the Kok II Government to open up the labour market completely and introduced instead a quota of 22,000 employees until May 2006. If the quota is not filled, the removal of the transitional arrangement can be considered (Kvist, 2004). Welfare access was also closed to migrants. In Sweden, the minority government proposed to issue residence and work permits only for those workers from the NMS who could prove that they had jobs meeting certain requirement with respect to national wage agreements and excluded individuals from the CEECs from several welfare benefits. However, the proposal of the Swedish government was overruled in Parliament, and Sweden is currently the only country where Community rules for labour mobility apply at present. The United Kingdom and Ireland decided to open-up their labour markets in principle to individuals from the new Member States, but they left also certain restrictions in place. Work permits are only issued for one year, and if migrants lose their jobs, the resident permits

\footnotetext{
${ }^{4}$ Beyond Austria and Germany this was Belgium, Finland, France, Greece and Luxembourg.
} 
can be withdrawn. Again, the access to welfare benefits remains restricted (Home Office, 2004a). This is a substantial change compared to the initial announcement of the British Government to open labour markets immediately after accession.

Finally, the three "undecided" countries -- Italy, Portugal and Spain - opted for restrictive provisions. Italy, in particular introduced a quota of 20,000 work permits for workers from the NMS, well below the projected immigration flows to this country (Alvarez-Plata et al., 2003) while Greece, Spain and Portugal decided to leave their immigration restrictions in place at least for the first two-year period.

Table 2.1

Transitional regulations in the EU-15

\begin{tabular}{|c|c|c|}
\hline & Access to labour market & Access to welfare benefits \\
\hline Austria & $\begin{array}{l}\text { Access to labour markets restricted at least for } 2 \text { years, } \\
\text { quotas for work permits. }\end{array}$ & Restricted. \\
\hline Belgium & Access to labour markets restricted at least for 2 years. & Restricted. \\
\hline Denmark & $\begin{array}{l}\text { General access to labour market, but obligations for } \\
\text { work and residence permits. Work permits issued only } \\
\text { for } 1 \text { year (EU-nationals: } 5 \text { years). }\end{array}$ & $\begin{array}{l}\text { Restricted, residence and } \\
\text { work permits can be withdrawn } \\
\text { in case of unemployment. }\end{array}$ \\
\hline Finland & Access to labour markets restricted at least for 2 years. & \\
\hline France & Access to labour markets restricted at least for 2 years. & Restricted. \\
\hline Germany & $\begin{array}{l}\text { Access to labour markets restricted at least for } 2 \text { years, } \\
\text { prolongation for further } 3 \text { years under discussion. }\end{array}$ & Restricted. \\
\hline Greece & Access to labour markets restricted at least for 2 years. & \\
\hline Ireland & $\begin{array}{l}\text { General access to labour market, but obligation to } \\
\text { register for work and residence permits. Work permits } \\
\text { issued first for limited time. Safeguard clause applies. }\end{array}$ & $\begin{array}{l}\text { Restricted, income support etc. } \\
\text { is granted only to individuals } \\
\text { which have a right for a } \\
\text { residence permit. }\end{array}$ \\
\hline Italy & $\begin{array}{l}\text { Access to labour markets restricted at least for } 2 \text { years, } \\
\text { quotas for work permits. }\end{array}$ & Restricted. \\
\hline Luxembourg & Access to labour markets restricted at least for 2 years. & Restricted. \\
\hline Portugal & $\begin{array}{l}\text { Access to labour markets restricted at least for } 2 \text { years, } \\
\text { quotas for work permits. }\end{array}$ & Restricted. \\
\hline Spain & $\begin{array}{l}\text { Access to labour markets restricted at least for } 2 \text { years, } \\
\text { bilateral agreement with Poland which permits limited } \\
\text { number of Polish nationals to work. }\end{array}$ & Restricted. \\
\hline Sweden & Community rule for free labour mobility applies. & Equal treatment. \\
\hline $\begin{array}{l}\text { United } \\
\text { Kingdom }\end{array}$ & $\begin{array}{l}\text { General access to labour market, but obligation to } \\
\text { register for work and residence permits. Work permits } \\
\text { issued first for limited time. Safeguard clause applies. }\end{array}$ & $\begin{array}{l}\text { Restricted, income support etc. } \\
\text { is granted only to individuals } \\
\text { which have a right for a } \\
\text { residence permit. }\end{array}$ \\
\hline
\end{tabular}

Altogether, we observed a race to the top in immigration restrictions vis-à-vis workers from the NMS. The final outcome was likely worse than had the restrictions being agreed at the EU-level. It was certainly more restrictive than in the case of the previous enlargement rounds, although income differences are in this case unprecedented (Boeri and Brücker, 2001). It is likely that the initial decision of the two largest immigration countries - Austria and Germany - to restrict migration from the new Member States 
fuelled fears that migration flows could be diverted into smaller countries, raising concerns about migration pressures there. Moreover, decisions to apply transitional periods in individual Member States have been carefully reviewed by other Member States and affected decisions elsewhere. For instance, the decision in the Netherlands to reverse the initial decision of the Kok II Government influenced the decisions of the Swedish government (Kvist, 2004) to renege on its previous commitments. Similarly, the Dutch Government is presently proposing to extend the transitional period for another two years and a key argument being used before the Parliament is that Germany is going to do the same. Significant press coverage of decisions made in neighbouring countries was provided in these countries.

The race to the top ended with four different transitional regimes: first, a restrictive immigration regime, which provides nationals from the new Member States no further rights than citizens to non-EEA countries. This implies that work permits are only issued in exceptional circumstances when it can be proved that neither natives nor other EU-nationals can fill the position. The main channel of entry is in these countries family reunification. This regime applies to Belgium, Finland, Germany, Greece, France, Luxembourg and Spain. The second regime adopts basically the same rules than the first one, but it opens the labour market beyond that by a quota for nationals from the new Member States (Austria, Italy, Netherlands, Portugal). Third, we have a number of countries which admit generally the access of nationals from the new Member States to their labour markets, but work and residence permits are only issued if certain requirements with regard to tariff wages, working conditions etc. are met. Moreover, the access to welfare benefits is limited and residence permits can be withdrawn in case of unemployment (Denmark, Ireland, UK). Finally, we have one country, Sweden, where due to the failure of the government to find a majority in Parliament, the rules of the Community for the free movement of labour apply (Table 2.1.).

\subsection{The consequences of the "race-to-the top": migration reduction and migration diversion}

When the Berlin Wall broke down in 1989, many observers expected a mass migration wave from the East to the West. Indeed, the income gap between the East and the West in Europe is substantial. The per capita GDP of the new Member States amounts in purchasing power parities to 49 per cent of incomes in the EU-15 (Eurostat, 2003), and in the neighbouring Commonwealth of Independent States to around one-fifth of the EU-15 level (Figure 2.3). At current exchange rates, the income gap is even larger. Nevertheless, with few exceptions, i.e. the cases of Albania and Eastern Germany, the removal of emigration barriers for the people in the former Eastern Bloc caused only moderate migration so far: cumulative net emigration since 1989 from the eight NMS and the two other accession candidates from Central and Eastern Europe to the EU can be estimated at around 1,1 million people, which equals one per cent of their population. No doubt, these moderate migration flows reflect also tight immigration restrictions in Western Europe. But also suggest that migration pressures are not as strong as to bypass national restrictions.

The transitional arrangements for immigration from the new Member States which we observe in the EU since the $1^{\text {st }}$ of May, 2004, affect the allocation of migration flows 
and stocks. They have two effects: on the one hand, they divert migration flows away from the countries which have decided to pursue restrictive immigration policies during the transitional periods to those which decided to open their labour markets, at least partially. On the other hand, transitional arrangements reduce migration stocks and flows relative to the scenario with free labour mobility, since the cost of migration increase with the distance from the country that would have been chosen otherwise. Distance is meant here to be a measure which captures not only geographical distance, but also the cultural, linguistic and social distance from the preferred destination. ${ }^{5}$

Figure 2.3

\section{The income gap in Europe, 2002}

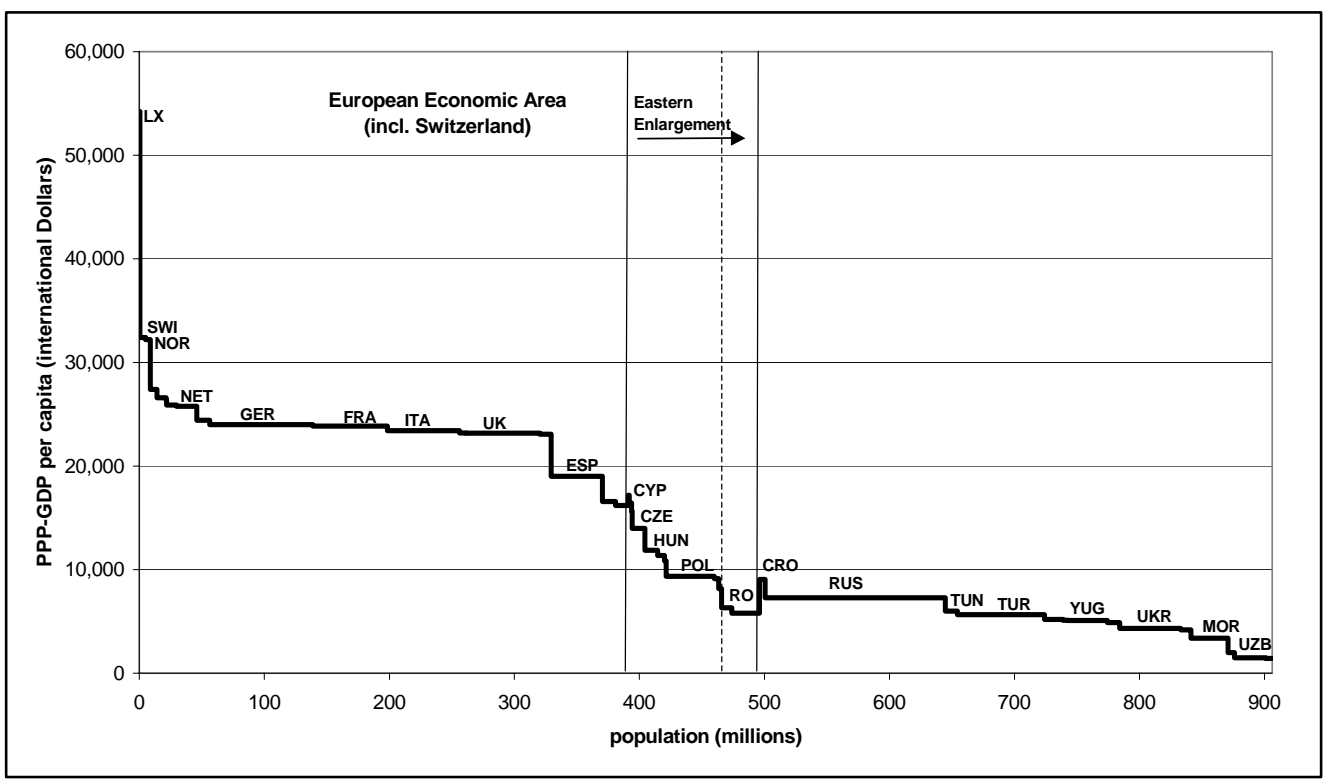

Table 2.2 displays the number of migrants from the CEEC-10 in the EU-15. It clearly documents that geographical distance is a key factor explaining the allocation of migrants from the CEEC-10 across the old EU Member States: the countries bordering the CEECs, i.e. Austria, Germany, Greece and Italy, absorbed more than 80 per cent of the migrants from the accession countries before the Enlargement. The share of migrants from the CEEC-10 in the population of these countries varies -- with the exception of Italy, which shares only a small border with Slovenia - between 0.7 and 1.0 per cent, while it is only 0.3 per cent at the average of the EU-15. This regional migration pattern has been rather stable during the 1990s and early 2000s, although the share of CEEC-10 migrants going to Germany has slightly declined in the wake of the economic stagnation in the recent years.

Note that all these countries attracting significant flows from the CEEC-10 imposed tight restrictions for immigration from the new Member States during the transitional periods. Among the 'Big-Four' in the old EU only the UK decided to open its labour market partially. It is too early to assess empirically whether and to what extent the transitional arrangements actually reduced migration flows and diverted migration away

\footnotetext{
${ }^{5}$ See Hansen (2003) for a formal exposition of this argument.
} 
from the traditional destinations of migrants from NMS. We provide below just some first scattered evidence. Before doing that, in Section 2.3.1 we provide the counterfactual, i.e. a projection of the migration potential under the hypothetical assumption of free labour mobility for all countries in the enlarged EU. Then, in Section 2.3.2 we will present reported migration patterns after Enlargement as deviations from this projection.

Table 2.2

Regional break-down of migrants from the CEEC-10 across the EU-15

\begin{tabular}{|c|c|c|c|c|}
\hline & year & $\begin{array}{c}\text { residents } \\
\text { from CEEC-10 }\end{array}$ & $\begin{array}{l}\text { as a percentage } \\
\text { of population }\end{array}$ & $\begin{array}{l}\text { as a percentage of } \\
\text { total CEEC-10 migrants }\end{array}$ \\
\hline Austria & 2001 & 78,886 & 1.0 & 7.3 \\
\hline Belgium & 2001 & 13,208 & 0.1 & 1.2 \\
\hline Denmark & 2004 & 11,596 & 0.2 & 1.1 \\
\hline Finland & 2001 & 13,639 & 0.3 & 1.3 \\
\hline France & 1999 & 51,942 & 0.1 & 4.8 \\
\hline Germany & 2003 & 614,094 & 0.7 & 57.0 \\
\hline Greece & 2001 & 71,742 & 0.7 & 6.7 \\
\hline Ireland $^{1)}$ & 2002 & 12,235 & 0.4 & 1.1 \\
\hline Italy ${ }^{2)}$ & 2001 & 102,105 & 0.2 & 9.5 \\
\hline Luxembourg & 2001 & 1,547 & 0.3 & 0.1 \\
\hline Netherlands & 2004 & 17,538 & 0.1 & 1.6 \\
\hline Portugal & 2001 & 963 & 0.0 & 0.1 \\
\hline Spain ${ }^{3)}$ & 2003 & 17,104 & 0.0 & 1.6 \\
\hline Sweden & 2003 & 24,295 & 0.3 & 2.3 \\
\hline UK & 2001 & 45,858 & 0.1 & 4.3 \\
\hline EU-15 & & $1,076,752$ & 0.3 & 100.0 \\
\hline
\end{tabular}

1) Only Latvia, Lithuania, Poland and Romania.- 2) Only Poland and Romania.- 3) Only Bulagria and Poland.

Sources: Authors' calculations based on figures reported by national statistical offices and population censuses.

\subsubsection{Looking for the counter-factual: East-West migration under free movement}

A number of studies tried to estimate the long-run migration potential from the CEECs. Although most of these studies estimate the long-run migration potential from the Central and Eastern European countries in the EU-15 at between 3 and 4 per cent (e.g. Layard et al., 1992; Bauer and Zimmermann, 1999; Boeri and Brücker, 2001; AlvarezPlata et al., 2003; Krieger et al., 2003), there exist also studies which obtain significantly lower (Fertig, 2001; Fertig and Schmidt, 2001; Dustmann et al., 2003) or higher estimates (Sinn et al., 2001, Flaig, 2001). The difference between the estimates can be largely traced back to different econometric estimation procedures. The methodological problems associated with estimates of the migration potential from the CEECs are discussed in some detail in Box 1. 


\section{Box 1 Methodological problems in estimating migration potentials}

Starting with the seminal contribution of Layard et al. (1992), numerous studies have tried to estimate East-West migration potential. Basically we can distinguish three main approaches in the literature: representative surveys, extrapolations from South-North to East-West migration, and forecasts based on econometric estimates of macro-migration models. Each approach has its advantages and disadvantages.

Representative surveys allow deep insights into migration intentions and the human capital characteristics of potential migrants (see Fassmann and Hintermann, 1996; IOM, 1999, Krieger et al., 2003). However, there are three problems which make it almost impossible to derive quantitative forecasts of the migration potential from them: first, we do not know how serious migration intentions revealed in surveys are, i.e. whether migration intentions result in actual movements. Second, surveys capture only the supply side and ignore demand side factors such as job opportunities and the availability of housing. Third, surveys cannot mirror the temporary dimension of migration appropriately: since only few migrants stay permanently abroad, a large number of individuals which migrate once in their lifetime can coincide with a small fraction of the population which stays at a certain point of time abroad. Most careful surveys of migration intentions make therefore adjustments, which scale down migration intentions of 10 per cent of the population or more to an actual estimate of the migration potential of between 2 and 4 per cent of the population (see e.g. Krieger et al., 2003).

Another strand of the literature extrapolated the number of South-North migrants in the 1960s and early 1970s to East-West migration (Layard et al. 1992; Bauer and Zimmermann, 1999). Note that the income gap between the Southern and the Northern European countries in the 1960s was similar to the gap between the EU-15 and the accession countries today (Maddison, 1995). In general, these extrapolation studies find a long-run migration potential of around 3 per cent of the population. However, in stark contrast to the conditions for South-North migration in the early 1960s and 1970s, the conditions for EastWest migration today are affected by imbalances in both the labour markets of the receiving and sending countries, incomplete recovery from the transition shock, and close geographical proximity. Thus, extrapolation studies can provide no more than a hint at plausible orders of magnitude.

The majority of the forecasts of East-West migration are based on econometric estimates of macro migration models, which explain migration flows or migration stocks by economic variables such as the income differential, (un-)employment rates in the sending and receiving countries, and some institutional variables. Although most studies employ the same set of explanatory variables, the estimates of the parameters, and, hence, of migration potentials differ considerably in the literature. The main problem of the econometric estimates can be traced back to the fact that they have to transfer parameter values which are estimated in another historical context and in another country sample are used for projections in the Central and Eastern European countries (Alecke et al., 2001; Fertig and Schmidt, 2001; Dustmann et al., 2003). The Central and Eastern European countries cannot be included in the original sample, since the iron curtain prevented effectively emigration. Thus, the projections rely implicitly on the assumption that the estimated parameter values remain constant not only across time, but also across space. Unfortunately, migration behaviour differs largely across countries due to differences in geography, language, culture, etc. This affects both the estimates of the intercept terms - which capture all factors which have a timeinvariant impact on migration - and the slope parameters.

There exist a number of alternative econometric models which impose different restrictions on the intercept, the slope parameters and the error terms. As an example, pooled OLS models, which are widely applied in the empirical literature, assume that both the intercept and the slope parameters are homogenous across countries, while fixed effects estimators allow for different intercepts, but assume that the slope parameters are homogeneous. Finally, there exist a number of heterogeneous estimators, which allow also the slope parameters to differ across countries and use for forecasts averages of the estimated parameters. Each estimation procedure has its trade-offs; the choice of the adequate estimation procedure is largely an empirical question.

A large number of different estimation procedures have been tested on their out-of-sample forecasting performance in the context of international migration (Alvarez-Plata et al., 2003; Brücker and Siliverstovs, 2004). The key results of these studies are that (i) fixed effects estimators, which allow for country-specific intercepts, but assume that the slope parameters are constant across countries, outperform all other estimators, (ii) the forecasting errors of pooled OLS models, which assume that both the intercept and slope parameters are homogenous across countries, are around twice as high as those of 
fixed-effects models, and (iii) that heterogeneous estimators which allow both the intercept and the slope parameters to differ across countries are clearly outperformed by standard panel estimators. Thus, we chose for the estimation of the migration potential here a standard fixed effects estimator. However, the reader should keep in mind that any migration forecast for the Central and Eastern European countries relies on a number of arbitrary assumptions, in particular the assumption that we can transfer the parameter values obtained from another country sample to the Central and Eastern European countries. All forecasts are therefore subject to a good deal of uncertainty and should be interpreted carefully.

The migration forecast is based here on the estimation of a macro model for the migration to Germany from a panel of European source countries for the period 19672001 (see Appendix A). Germany has been chosen because it is the main destination for migrants from the CEECs, and it reports stocks and flows of migrants at relatively long series, unlike many other EU countries.

Table 2.3

Germany: potential migration from the accession countries, 2004-2030

\begin{tabular}{|c|c|c|c|c|c|c|c|c|c|c|c|}
\hline & 2004 & 2005 & 2006 & 2007 & 2008 & 2009 & 2010 & 2015 & 2020 & 2025 & 2030 \\
\hline & \multicolumn{11}{|c|}{ net migration (persons) } \\
\hline CEEC-10 & 225453 & 258201 & 239719 & 203173 & 163623 & 127916 & 98420 & 29379 & 16195 & 12716 & 10449 \\
\hline CEEC-8 & 155561 & 169031 & 155228 & 132003 & 107644 & 85798 & 67691 & 23551 & 13284 & 9750 & 7197 \\
\hline \multirow[t]{2}{*}{ CEEC-2 } & 69892 & 89171 & 84491 & 71169 & 55979 & 42118 & 30729 & 5828 & 2911 & 2965 & 3252 \\
\hline & \multicolumn{11}{|c|}{ foreign population (persons) } \\
\hline CEEC-10 & 824202 & 1082404 & 1322123 & 1525295 & 1688918 & 1816834 & 1915254 & 2158985 & 2257596 & 2327059 & 2383958 \\
\hline CEEC-8 & 628065 & 797096 & 952324 & 1084327 & 1191971 & 1277768 & 1345459 & 1527200 & 1608334 & 1663647 & 1704652 \\
\hline CEEC-2 & 196137 & 285308 & 369799 & 440968 & 496947 & 539066 & 569795 & 631785 & 649262 & 663412 & 679306 \\
\hline
\end{tabular}

The projections of the migration potential in Table 2.3 are based on the assumption that the GDP per capita between the new Member States and the EU-15 converges at a rate of 2 per cent p.a. This speed of convergence is consistent with a number of studies for the EU and other European market economies (e.g. Barro and Sala-i-Martin, 1991; 1995). It implies that halving the initial gap in per capita income levels will take 35 years. Growth rates in the new Member States since the end of the transitional recession fit pretty well into this projection, although the growth experience differs from country to country. Unemployment rates are hard to predict. We assume therefore that unemployment rates remain constant during the projection period at a level which is equal to the average rate in the respective countries during the last five years. This is consistent with the observation of jobless growth in the CEEC-10 (Boeri and Garibaldi, 2005).

The projection for Germany is displayed in Table 2.3. The scenario predicts under the hypothetical assumption of a removal of the migration barriers in 2004 a net migration of 156,000 persons to Germany from the eight new Member States (CEEC-8) and of 225,000 persons for all ten accession countries (CEEC-10). Net migration achieves its peak one year later involving around 170,000 and 260,000 persons from the CEEC-8 and the CEEC-10, respectively, and then declines to attain six years later about onethird of this level. The long-run migration stock is attained 25 years after the introduction of the free movement at a foreign population of 1.7 and 2.4 million persons from the CEEC-8 and the CEEC-10, respectively. The simulation results also demonstrate that transitional arrangements have no impact on the long-run migration potential, since the convergence of per capita income levels is relatively slow (not 
displayed here). Of course, all these results rely on a number of arbitrary assumptions and can provide no more than a rough guidance as to the actual magnitudes involved.

Table 2.5

EU-15: potential migration from the eight NMS, 2004-2030

\begin{tabular}{|c|c|c|c|c|c|c|c|c|c|c|}
\hline & \multicolumn{5}{|c|}{ net migration } & \multicolumn{5}{|c|}{ foreign population } \\
\hline & 2004 & 2005 & 2010 & 2020 & 2030 & 2004 & 2005 & 2010 & 2020 & 2030 \\
\hline & \multicolumn{10}{|c|}{ persons } \\
\hline Austria & 19,983 & 21,714 & 8,696 & 1,706 & 924 & 80,681 & 102,394 & 172,837 & 206,605 & 218,978 \\
\hline Belgium & 3,346 & 3,636 & 1,456 & 286 & 155 & 13,508 & 17,144 & 28,938 & 34,592 & 36,664 \\
\hline Denmark & 2,937 & 3,192 & 1,278 & 251 & 136 & 11,860 & 15,052 & 25,406 & 30,370 & 32,189 \\
\hline Finland & 3,455 & 3,754 & 1,503 & 295 & 160 & 13,949 & 17,703 & 29,883 & 35,721 & 37,860 \\
\hline France & 13,158 & 14,297 & 5,726 & 1,124 & 609 & 53,124 & 67,421 & 113,803 & 136,038 & 144,185 \\
\hline Germany & 155,561 & 169,031 & 67,691 & 13,284 & 7,197 & 628,065 & 797,096 & $1,345,459$ & $1,608,334$ & $1,704,652$ \\
\hline Greece & 18,174 & 19,747 & 7,908 & 1,552 & 841 & 73,374 & 93,121 & 157,184 & 187,895 & 199,147 \\
\hline Ireland & 3,099 & 3,368 & 1,349 & 265 & 143 & 12,513 & 15,881 & 26,806 & 32,044 & 33,963 \\
\hline Italy & 25,865 & 28,105 & 11,255 & 2,209 & 1,197 & 104,428 & 132,533 & 223,709 & 267,417 & 283,431 \\
\hline Luxembourg & 392 & 426 & 171 & 33 & 18 & 1,582 & 2,008 & 3,389 & 4,052 & 4,294 \\
\hline Netherlands & 4,443 & 4,827 & 1,933 & 379 & 206 & 17,937 & 22,764 & 38,425 & 45,933 & 48,683 \\
\hline Portugal & 244 & 265 & 106 & 21 & 11 & 985 & 1,250 & 2,110 & 2,522 & 2,673 \\
\hline Spain & 4,333 & 4,708 & 1,885 & 370 & 200 & 17,493 & 22,201 & 37,474 & 44,796 & 47,479 \\
\hline Sweden & 6,154 & 6,687 & 2,678 & 526 & 285 & 24,848 & 31,535 & 53,230 & 63,629 & 67,440 \\
\hline UK & 11,617 & 12,623 & 5,055 & 992 & 537 & 46,901 & 59,524 & 100,473 & 120,104 & 127,296 \\
\hline EU-15 & 272,761 & 296,378 & 118,689 & 23,292 & 12,619 & $1,101,249$ & $1,397,627$ & $2,359,127$ & $2,820,052$ & $2,988,936$ \\
\hline
\end{tabular}

Sources: Authors' calculations. See text for assumptions of projection and extrapolation.

What are the implications of these projections for the other EU-15 countries? Although time-series does not exist for all EU-15 countries, available data suggest that the regional distribution of migrants across the EU-15 was relatively stable during the 1990s and early 2000s. This can, inter alia, be traced back to network effects, which reinforce regional migration patterns once they have been established. Under the strong assumption that the regional distribution of migrants across the EU displayed in Table 2.2 remains constant over time, we can extrapolate the German results to remaining EU countries. This has been done in Table 2.5. Assuming then that all EU-15 introduce free movement in 2004, we would get an initial net migration of 270,000 persons from the eight NMS in 2004, and of around 300,000 persons one year later. The long-run migration potential is achieved at around 3.0 million persons roughly 30 years later. Note that projections which are based on econometric estimates for other countries yield similar results: For instance, Dustmann et al. (2003) estimated in a study for the Home Office the initial net migration for the United Kingdom at between 4,900 and 12,600 persons p.a., which is in the range of our projections (11,600 persons).

\subsubsection{Is there migration diversion after Enlargement?}

At present, there is limited information on migration trends since the $1^{\text {st }}$ of May, 2004. Available evidence suggests that the transitional arrangements resulted in both, the diversion and the reduction of migration flows relative to the case of free labour mobility. First, the Home Office in the United Kingdom reports that more that 130,000 nationals from the new Member States have registered for work between May and December 2004, of which 40 per cent have been already in the UK prior to Enlargement (Home Office, 2004b). If these figures imply that 80,000 persons from the eight new Member States migrated to the UK in 2004, this would be more than five times the migration potential of the projections provided in Section 2.3.1. However, the figures 
published by the Home Office cover also temporary migrants like seasonal workers, and not all individuals who register do later actually take-up jobs, so that actual immigration might be lower. Yet, given that the official number of nationals from the CEECs has been below 50,000 persons at the beginning of the 1990s, the figures published by the UK Home Office point to a substantial increase in immigration.

For Ireland, a country which pursues the same immigration policies as the UK during the transitional period, we have contradictory information. On the one hand, 7,500 work permits were issued to nationals from the NMS from January 1 to October 31, 2004, down from 20,000 in the 12 months from January 1 and December 31 in 2003. On the other hand, the Irish government reports that 31,000 personal public service numbers (certificates which are necessary for a work permit ${ }^{6}$ ) were issued to nationals from the NMS in the five months from May $1^{\text {st }}$ to October $31^{\text {st }}$, 2004, pointing to a substantial increase in the flows from CEECs relative to 2003. Thus, it is possible that migration flows into Ireland have been several times higher than predicted in the counterfactual scenario.

Some diversion of migration flows from CEECs was also observed in the Nordic countries. In Sweden, the only EU country without transitional arrangements, the number of work permits doubled from 2,097 in 2003 to 3,966 in 2004. However, this figure is below the predictions in the counterfactual scenario $(6,200)$. In Norway, which partially opened its labour market and is booming because of the oil price hike, the number of released work permits increased from 18,170 in 2003 to 25,325 in 2004 . $^{7}$ Meanwhile the Nordic countries tightly restricting migration from the CEECs experienced modest or declining migration flows. In Denmark, 2,048 work permits were issued in 2004. Comparable figures for 2003 are not available here. However, the number is pretty low relative to the predicted inflow of 3,000 persons. In Finland, work permits dropped from 6,747 in 2003 to 2,169 in 2004. ${ }^{8}$ However, the Finnish Ministry of Labour reports that the number of posted workers has increased substantially since Eastern Enlargement.

No information is available as yet on migration to the traditional destination of migrants from the CEECs, namely Austria, Germany and Italy, although according to statements of Government officials it would seem that migration from the CEECs has been stable after the Enlargement.

Overall, the scattered information available at the time of writing point to some diversion of flows from countries tightly closing borders to countries with more liberal rules with respect to migration from the NMS. This is particularly true for the English speaking countries, where migration figures exceed by far those of the migration projections. The Eastern Enlargement episode so far suggests that asymmetries in migration restrictions affect the geographical orientation of migration flows. These diversion effects may become over time more important as networks of citizens from

\footnotetext{
${ }^{6}$ We are grateful to Frank Berry and Gerry Hughes who provided information on work permits and personal public service numbers in Ireland.

${ }^{7}$ We are grateful to Jon Erik Dølvik from the Fafo Institute for Labour and Social Research for the provision of the data for the Nordic countries.

${ }^{8}$ However, the drop in Finish figures can be at least partially explained by the fact that no work permits are required for seasonal work below three month since May 2004.
} 
the CEECs are established in the new destinations, although they are unlikely to become as marked as in the case of differences in the enforcement of controls across the USMexico border (Boeri, Hanson and McCormick, 2001) because there are language barriers in Europe.

\section{THE ECONOMIC COSTS OF MIGRATION RESTRICTIONS}

\subsection{Is migration needed in open economies?}

Insofar as asymmetries in transitional periods affect the destination of flows from the CEECs, they are also likely to reduce their magnitude. In this Section we evaluate these scale effects and provide some estimates of the overall costs of un-coordinated migration restrictions.

Old and new Member States differ markedly in terms of factor endowments and factor productivities. The book value of the physical capital stock per capita in the NMS is currently about one-tenth of the level in the EU-15. International migration is just one of the potential channels leading from these differences in factor endowments to a new allocation of resources in the EU-25. The other two channels, trade and capital movements, have already been operating since the beginning of transition to a market economy.

The economic impact of migration depends inter alia on whether and to what extent international migration substitutes or complements trade and capital mobility. If migration substitutes trade and capital movements, an isolated analysis of the effects migration tends to overstate its impact, since some of the effects of trade and capital mobility are lost. If it complements trade and capital mobility, an isolated analysis of migration tends to understate its effects, since we have to consider the effects of additional trade and capital movements as well. Unfortunately, economic theory does not provide clearcut answers to the question whether trade and factor mobility are substitutes or complements (see Box 2).

\section{Box 2 Does migration substitute trade and other factor flows?}

In the standard Heckscher-Ohlin-Samuelson (HOS) framework, trade and factor mobility are substitutes as pointed out by Robert Mundell (1957) almost 50 years ago. Consider the simple case where two countries produce two goods with two factors and identical technologies. If barriers to trade are removed, the capital abundant country will export goods which use capital intensively in production, and import goods which use labour intensively in production. The price for the capital intensive goods will rise and that for the labour intensive good will decline, while profits will increase and wages fall. The reverse holds for the labour abundant country. Under certain assumptions on technologies and preferences, factor prices will eventually equalise (Samuelson 1949; Lerner 1952). Hence, no incentives for factor mobility remain. Analogously, the opening of capital or labour markets will result in the movement of the abundant factor into the country where this factor is scarce, leading to factor (and good) price equalisation as well. Thus, factor mobility reduces the incentives for trade in this framework: it is sufficient to open any of the three channels - trade, capital or labour mobility - to achieve factor price equalisation. 
However, the predictions change significantly if we relax some of the most restrictive assumptions of the HOS model. The assumptions on technologies are particularly important. If there is a productivity gap between countries, which holds across all sectors, then trade will equalise only relative factor incomes (Trefler, 1987). This means that incentives for factor mobility will remain even if all barriers to trade are removed. If instead cross-country productivity gaps vary across sectors, trade and factor mobility can be complements: Assume for instance that two countries have identical factor endowments, but that one the two has a (Hicks-neutral) productivity advantage in the capital intensive sector. In this case this country will export capital intensive goods and import labour intensive goods, which will raise profits and reduce wages at home, whilst in the other country wages increase and profits fall. It follows that trade increases the incentives for labour to migrate from the country which has a comparative advantage in the capital intensive good to the country which has a comparative advantage in labour intensive production (Markusen, 1983). Moreover, trade theory has discussed a number of other cases where trade and factor movements are complements rather than substitutes: In case of specific factors, i.e. factors which are not mobile across sectors, trade may induce more factor mobility, making economies more dissimilar, and thus increasing even further the trade volume (Venables, 1999; Collins et al., 1999). In trade models with increasing returns to scale and monopolistic competition, factor mobility allow countries to attain economies of scale, increasing the real return to the factors of production at home, and, via this channel, induce further factor inflows. Thus, trade liberalisation in these models stimulates larger migration flows (Krugman, 1991; Venables 1999).

As economic theory does not provide unambiguous predictions, empirical evidence may offer some guidance. In the fifteen years since the fall of the Berlin Wall, East-West trade and capital flows increased dramatically, without reducing differences in income per capita and factor prices. Between 1988 and 2003, trade between the EU-15 and the NMS grew approximately by a factor of $6,{ }^{9}$ and the stock of foreign direct investment increased from virtually zero to 142.2 billion Euro (roughly one fourth of GDP in the NMS) by 2003 (Hunya, 2005). Nevertheless, economic convergence is slow: from the through of the transitional recession, GDP per capita are recovering in the region at an average annual rate of 3.4 per cent, compared with 2.1 in the EU- $15^{10}$. Thus, the speed of convergence is in line with the rate estimated by Barro and Sala-i-Martin (1991, 1995) drawing on data on the post-war period in Europe and the US. At this rate, any initial gap in per capita income levels will be halved every 35 years. Thus, even if trade and capital movements substitute migration, differences in wage levels will create monetary incentives for migration for decades. Following the predictions in the studies just reviewed in the previous Section, we can expect that free movement would yield an additional migration of 2 to 3 per cent of the population in the NMS moving to the EU15 over the next 30 years, assuming a Barro-type speed of convergence.

In this Section, we analyse the benefits and costs of East-West migration in the enlarged EU in a highly stylised model using the present differences in GDP and wage levels. This model allows us calibrate the effects of migration for the receiving and the sending countries under different assumptions as to the composition of the migrant population, the presence of institutions hindering wage adjustment, regional disparities in income levels and employment opportunities, as well as different levels of welfare benefits. Our goal is not to provide a formal cost-benefit analysis of migration restrictions, but simply to evaluate the sign of the interactions between, on the one-hand, un-coordinated migration restrictions and, on the other hand, different labour market institutions taking the example of the Eastern Enlargement. We also analyse whether and to what extent

\footnotetext{
${ }^{9}$ Authors' calculations based on the Direction of Trade Statistics of the IMF.

${ }^{10}$ Authors calculations based on the data provided by UN/ECE (2005).
} 
migration may reduce capital mobility in order to get some clues as to whether the effects of migration could be lower when accounting for capital inflows.

Box 3 outlines the simulation model and lists the assumptions which provide the background for our analysis. The technical details of the model are presented in Appendix B. A natural starting point is the textbook case of a closed-economy with labour market clearing. This is our reference case in the calibrations. At the current income disparities between the old the new Member States, the gains from potential migration can be substantial. Most of these gains accrue, however, to the migrants and their families, generating only small incentives for the receiving countries to open up their labour markets. Under more realistic assumptions as to wage adjustment in the receiving country, migration increases unemployment in the receiving country. Although the aggregate income gains from migration are still sizeable, incomes of the native population fall in this case. Thus, there is a trade-off between the overall gains from migration in the enlarged EU and the interests of the receiving countries (Section 3.2). However, migration can also "grease the wheels" (Borjas, 2001) of the labour market in the recipient countries, which display very low regional mobility of the workforce and often centralised wage setting institutions not compensating for regional differences in labour productivity.

Allowing for regional differences in income levels and employment opportunities in the host country we obtain higher aggregate gains from migration and a lower adverse impact on the native population. Nevertheless, incentives for closing borders remain also in this case (Section 3.3). Welfare benefits affect income of natives and migrants via various channels. They do it directly, by redistributing income from the natives to the migrant population if migrants are more than proportionally affected by unemployment and other social risks, as well as indirectly, by affecting the scale and composition of the migrant population. Although the impact of different levels of welfare benefits are moderate, within realistic ranges of welfare provision in the EU, the income of the native population declines as the generosity of the welfare system increases. However, the aggregate GDP in the enlarged EU is larger when welfare benefits are higher in the receiving countries, since they increase incentives to move not only for welfare recipients, but also for other migrants. Thus, there is once more a tradeoff between aggregate welfare in the enlarged EU and the interests of the receiving countries (Section 3.4).

\section{Box 3 Verbal description of the model}

The simulations in the following sections are based on a highly stylised model of two economies, which produce one good and apart from migration are closed. ${ }^{11}$ Each economy's output is produced with skilled labour, non-skilled labour and physical capital. The production function is characterised by constant returns to scale and is approximated by a simple Cobb-Douglas-function. Using a Cobb-Douglas function implies that the elasticity of substitution between the factors of production is one. Bauer and Zimmermann (1997) provide evidence that this is a reasonable approximation for the EU-15. For the US, Murphy and Katz (1992) estimate the elasticity of substitution between skilled and unskilled workers at 0.7, and Borjas 1997, 1999) at 0.3, using another definition of the respective groups. Thus, some uncertainty with regard to the actual elasticity of substitution surrounds our results.

11 The model employed here draws on similar models by Levine (1999) and Bauer and Zimmermann (1997), although it includes a number of additional features. 
For convenience, the domestic labour supply is treated as inelastic, and physical capital and the human capital endowments of natives and migrants are assumed to be fixed. This means that we simulate the case of a short-term adjustment. In the long-run, the economy adjusts to a given stock of migrants by the accumulation of physical and human capital, such that the effects of a one-time increase of the labour supply through migration are expected to disappear over time.

Due to a lack of data we use the share of manual and non-manual workers in the labour force as an approximation for the shares of unskilled and skilled labour, although this proxy is certainly crude. In the EU-15 the proportion of manual workers is around 40 per cent, in the new Member States around 50 per cent. Based on the book-value of fixed assets, the physical capital stock can be estimated in the new Member States at around 20 per cent of that in the EU-15. The share of manual workers in total income has been estimated in the EU-15 as being at 26 per cent, that of non-manual workers at 45 per cent, and that of capital at 29 per cent (Bauer/Zimmermann, 1997). In the new Member States we assume that the respective shares are for manual labour 29 per cent, for non-manual labour 42 per cent, and for capital 29 per cent. Finally, we assume that production technologies are less productive in the new Member States, i.e. the productivity parameter in the production function has a value of 0.8 in the new Member States and of 1 in the EU-15. Under these assumptions, the difference in GDP per capita and wage levels of the model roughly matches the actual income gap.

Finally, we assume for convenience that the receiving and the sending country have the same population size, i.e. that an emigration of one per cent of the labour force equals an immigration of one per cent. This distorts of course the actual picture since the population of the EU-15 is almost four times larger than that of the new Member States, but it may roughly capture the situation for Austria and Germany, whose population has almost the same size as that of the new Member States and who absorb around 70 per cent of the migrants from there.

The impact of migration on capital movements is ambiguous and, in any event, much too small to reduce the impact of migration on GDP and on the income distribution. However, capital movements reduce migration more substantially (Section 3.5). Our findings are broadly consistent with the simulation results of more complex CGEmodels, which consider both the effects of migration on capital accumulation and the interaction with trade. At the same time, results from econometric studies on migration in Europe suggest that wage and employment elasticities to immigration may be smaller than in our simulations (Section 3.6)

\subsection{Adjustment with and without wage rigidities}

The impact of migration on welfare in the receiving and the sending countries depends heavily upon the assumptions as to the flexibility of labour markets. In addition to a perfectly flexible labour market, we consider here different levels of wage rigidity. In the scenarios with rigid wages, wages are fixed at the beginning of each period by a bilateral bargaining monopoly of employer federations and trade unions. Next, firms hire manual and non-manual workers until their marginal product equals the agreed wage rate, as in a right-to-manage model. As the participants in wage negotiations are aware that employment should be on the labour demand curve, collective agreements are somewhat (albeit not fully) responsive to unemployment. As part of the labour force remains unemployed, not all migrants are absorbed by the host labour markets. Following the Harris-Todaro tradition, we assume that jobs are allotted within the domestic and foreign labour forces by a random draw. The employment opportunities of migrants are, however, assumed to be lower than those of natives. This implies that the unemployment risk is partially shifted from natives to immigrants. 
In particular, in the simulations we assume that the unemployment risk of foreigners is twice as large as unemployment among natives. This is broadly in line with observed unemployment differentials between domestic and foreign population, conditioning on education levels. As long as education levels of the migrants coming from the NMS are above those of the traditional immigrant groups, our assumption is rather conservative as to the employment opportunities of workers coming from the CEECs. Finally we assume that unemployed individuals receive an unemployment benefit, which is proportional to the post-tax wage as it is the case in many continental European countries such as Austria and Germany. Unemployment benefits are financed out of a uniform tax on labour income, which is endogenously set at the level clearing the social security budget. Thus, in this setting migration can affect the incomes of natives in the receiving and sending countries as well as incomes of migrants via three main channels:

- changes in factor incomes, i.e. changes in wages and capital rents;

- changes in employment opportunities;

- the tax rate. 
Table 3.1

Impact of Migration on Income and Employment

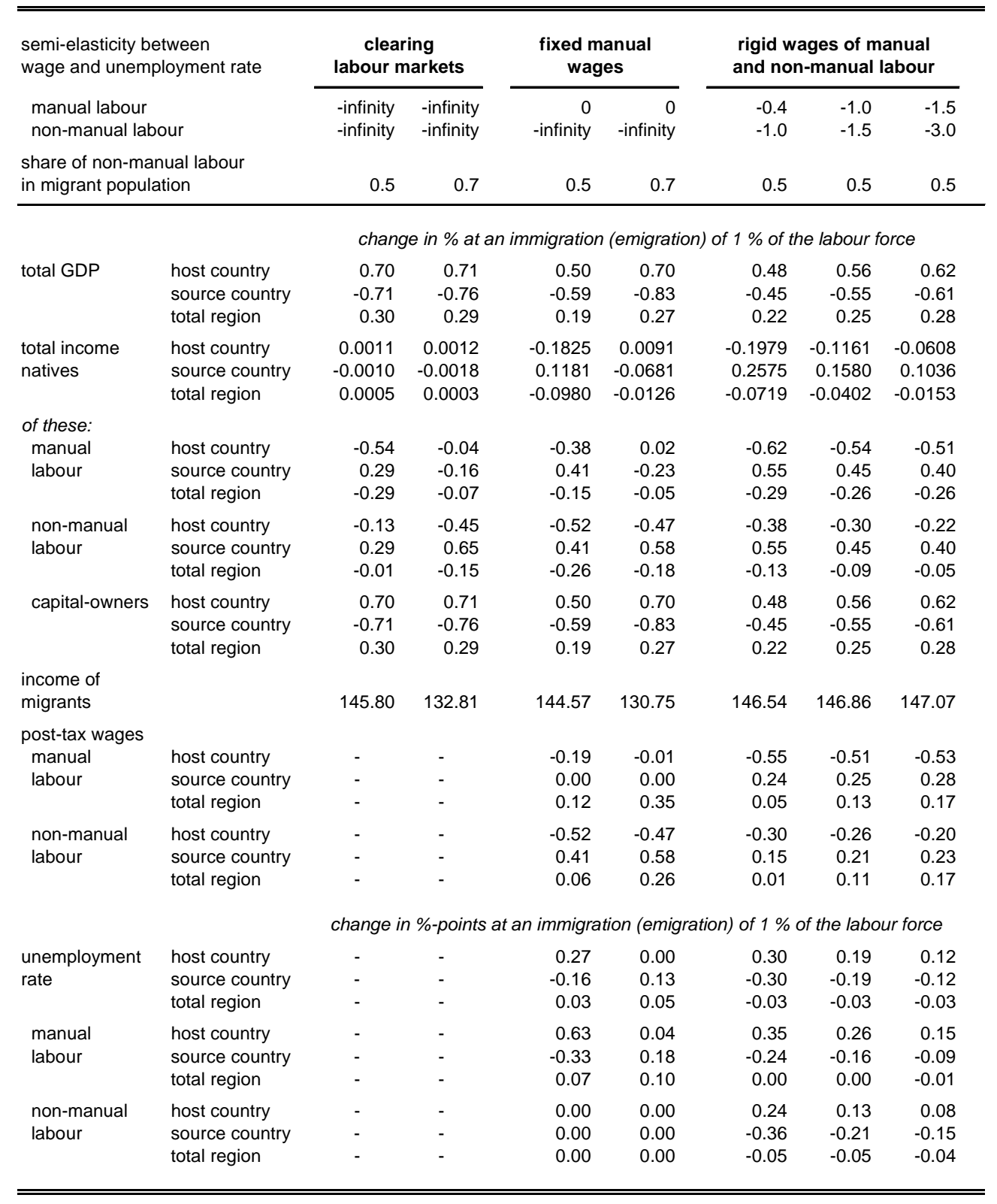

Source : Calculations of the authors. See text for assumptions.

Table 3.1 displays the results of the model under three alternative scenarios. In the first scenario, our baseline, it is assumed that labour markets are clearing. In the second scenario, it is assumed that wages of manual workers are completely rigid, while wages for non-manual workers are fully flexible. Finally, the third scenario adopts the milder form of wage rigidity discussed above to both segments of the labour market. The semielasticity of the wage rate is consistent with many empirical estimates (Bean et al.,, 1986; Blanchflower and Oswald, 1995; Newell and Symons, 1985; Layard et al., 1991; 
see Levine, 1999 for similar applications). ${ }^{12}$

The first scenario assumes that 50 per cent of the migrant population are non-manual workers, the second scenario that 70 per cent are non-manual workers. Although the composition of the migrant population affects the distribution of income in the receiving countries, its impact on the aggregate in the sending and receiving countries is negligible. Under labour market clearing, gains are substantial: an immigration of one per cent of the population increases the GDP of the total region in both scenarios by around 0.3 per cent. Given that another two or three per cent of the population from the new Member States might migrate in case of a free movement, this figure gives an idea on the potential losses of migration restrictions for the enlarged EU. However, the gains from migration are not uniform across the board: most of the gains accrue to the migrants, whose income increase between 130 and 150 per cent in the different scenarios. In the receiving countries, the wages of manual or non-manual workers decline from 0.04 to 0.56 per cent, depending on the assumptions which are made as to the skill composition of the migrant population, while labour wins in the source countries. Although the total gains from migration are substantial, the aggregate gains for natives in the receiving countries and the losses for factor incomes of natives in the sending countries are negligible.

In the scenarios with labour market rigidities the gains from migration drop to 0.19 to 0.28 per cent, depending on the assumptions on the extent of the rigidities. The two scenarios which assume that wages for manual labour are fully rigid, while labour markets for non-manual workers clear, employ again different assumptions as to the composition of the migrant population. In case of a high share of non-manual workers in the migrant population, the GDP gains increase substantially in the receiving country, since the demand for non-manual workers tends to increase. The last three scenarios employ more realistic assumptions as to the semi-elasticity of wages with regard to the unemployment rate. They might represent labour market conditions in different countries, e.g. Germany at the one end, and the UK at the other end of the spectrum. Depending on these assumptions, the unemployment rate in the receiving countries may increase between 0.12 and 0.3 per cent, while the post-tax wages for manual workers drop by around 0.5 per cent and those for non-manual workers by between 0.2 and 0.3 per cent. Moreover, aggregate income of natives fall in the receiving countries between 0.06 and 0.2 per cent.

Thus, with wage rigidities, unemployment and other welfare benefits, migration poses a policy dilemma: despite substantial income gains in the total region, migration involves not only a redistribution of income in the receiving country: it generates also an income loss for the total native population there. Although this loss is pretty small according to our simulations, it generates incentives for a closing-the-door policy which may prevent that the gains from migration in the total region are realised.

\footnotetext{
${ }^{12}$ E.g., Blanchflower and Oswald (1994) find in many industrialised countries an elasticity between the wage and the employment rate of around 0.1. Transforming the semi-elasticities of our model into elasticities at the assumed unemployment rates, we get for the host countries an elasticity of between 0.04 and 0.15 for manual workers, and between 0.05 and 1.5 for non-manual workers. The elasticities are higher in the sending countries, since the unemployment rate are higher there as well.
} 


\subsection{Can immigration from the new Member States grease EU's labour markets?}

Regional labour mobility in the EU-15 is low: only about 1 workers out of 200 changes residence every year compared with 5 in the US (Boeri, McCormick and Hanson, 2001, Barro and Sala-i-Martin, 1991, 1995; Decressin and Fatas, 1995; Puhanyi, 2000). According to George Borjas (2001), international migration can "grease the wheels of the labour market" when domestic labour mobility is low. Suppose that in the host country, say Germany, there are two regions: a low wage region and a high wage region. Regional migration equalises the costs and benefits of moving from the lowwage to the high-wage region for the marginal native migrant. Hence, there is no regional migration of natives. Moreover, let's assume that the incentives for domestic capital mobility have disappeared, i.e. that the profits from investing in the low wage region equals its costs. As interregional wage differentials in Germany are lower than those between Germany and any CEEC, say Poland, incentives to migrate into the highwage region are higher for Polish workers than for the German workers. Hence, immigration from Poland reduces the regional wage differential in the Germany. This increases the productivity of the remaining production factors, and the impact of international migration on GDP in Germany is higher than in the baseline. Moreover, under centralised wage setting imposing to the low-productivity region the wage clearing the labour market in the high productivity region, migration reduces unemployment also in the low wage region, as discussed in Box 4.

Box 4 Effects of migration in countries with centralised wage-setting and no labour mobility

NORTH

SOUTH

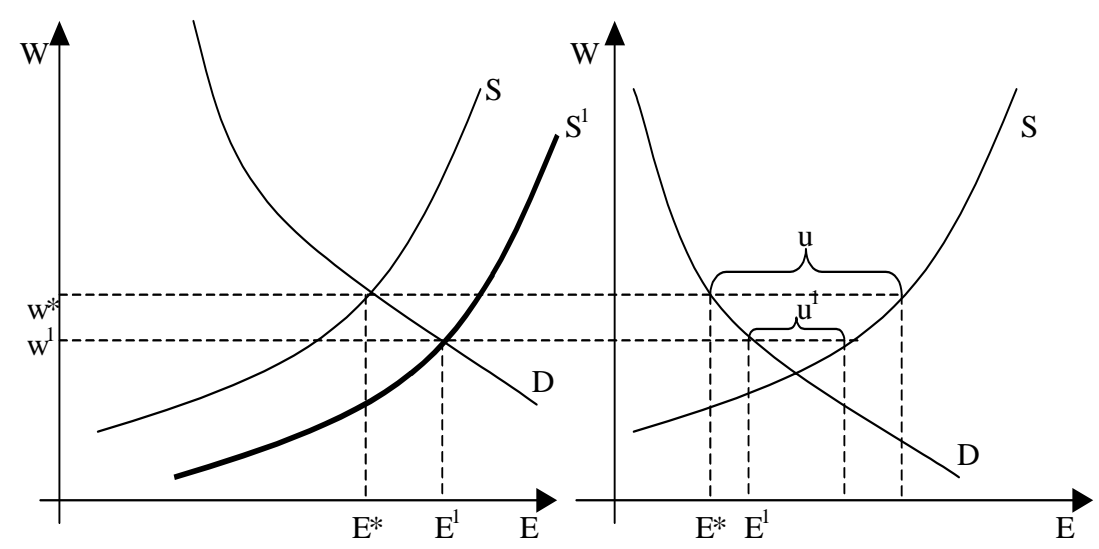

In presence of wage compressing institutions, international migration can reduce unemployment also in the low-productivity (high-unemployment) regions. This additional "greasing the wheels" effect of migration is visually characterised in the above diagram. The panel on the left-hand side shows the market-clearing wage prevailing in the dynamic regions (called here the North) which is also paid - due to the imposition of the same contractual minima throughout the country - in the South. At the initial equilibrium, the South experiences unemployment as the Northern wage acts as a binding minimum wage. Migration has two useful functions in this context. On the one hand, it increases employment and reduces wages in the North by shifting to the right labour supply (as shown by the bold line, S'). On the other hand, migration, by acting on Northern wages, reduces labour costs also in the South (from $\mathrm{W}^{*}$ to $\mathrm{W}^{1}$ ) allowing partially to absorb its unemployment pool there (which shrinks from $u$ to $\mathrm{u}^{1}$ ). 
Note that persisting regional wage and employment differences are hardly unrealistic. The share of foreign employees from CEECs in the Eastern German labour force where wages are at 70 per cent and unemployment rates around twice as high as in the country average-is only one-third of the German average. At the Bavarian border to the Czech Republic -where wages are significantly above and unemployment rates below the country average - the share of migrants to the total population is roughly three times the country average (Boeri and Brücker et al., 2001). Similarly only 5 migrants out of 100 coming to Italy live in the Mezzogiorno, where unemployment is almost 3 times as large as in the North and wages are 15 to 20 per cent lower.

Table 3.2

Impact of migration in economies with regional disparities

\begin{tabular}{|c|c|c|c|c|c|c|c|}
\hline & & \multicolumn{2}{|c|}{ clearing labour markets ${ }^{1}$} & \multicolumn{2}{|c|}{$\begin{array}{l}\text { clearing labour markets in } \\
\text { high-wage region }\end{array}$} & \multicolumn{2}{|c|}{$\begin{array}{l}\text { higher wage flexibility in high- } \\
\text { wage region }^{3}\end{array}$} \\
\hline & & $\begin{array}{l}\text { heterogeneous } \\
\text { regions }\end{array}$ & $\begin{array}{l}\text { homogeneous } \\
\text { regions }\end{array}$ & $\begin{array}{l}\text { heterogeneous } \\
\text { regions }\end{array}$ & $\begin{array}{l}\text { homogeneous } \\
\text { regions }\end{array}$ & $\begin{array}{l}\text { heterogeneous } \\
\text { regions }\end{array}$ & $\begin{array}{l}\text { homogeneous } \\
\text { regions }\end{array}$ \\
\hline & & \multicolumn{6}{|c|}{ change in $\%$ at an immigration (emigration) of $1 \%$ of the labour force } \\
\hline total GDP & $\begin{array}{l}\text { host country } \\
\text { source country } \\
\text { total region }\end{array}$ & $\begin{array}{r}0.87 \\
-0.71 \\
0.42\end{array}$ & $\begin{array}{r}0.70 \\
-0.71 \\
0.30\end{array}$ & $\begin{array}{r}0.90 \\
-0.55 \\
0.51\end{array}$ & $\begin{array}{r}0.57 \\
-0.55 \\
0.26\end{array}$ & $\begin{array}{r}0.81 \\
-0.55 \\
0.44\end{array}$ & $\begin{array}{r}0.57 \\
-0.55 \\
0.26\end{array}$ \\
\hline $\begin{array}{l}\text { total income } \\
\text { natives }\end{array}$ & $\begin{array}{l}\text { host country } \\
\text { source country } \\
\text { total region }\end{array}$ & $\begin{array}{r}0.0028 \\
-0.0010 \\
0.0017\end{array}$ & $\begin{array}{r}0.0011 \\
-0.0010 \\
0.0005\end{array}$ & $\begin{array}{l}0.0029 \\
0.1580 \\
0.0438\end{array}$ & $\begin{array}{r}-0.1210 \\
0.1580 \\
-0.0468\end{array}$ & $\begin{array}{r}-0.1167 \\
0.1580 \\
-0.0441\end{array}$ & $\begin{array}{r}-0.1210 \\
0.1580 \\
-0.0468\end{array}$ \\
\hline $\begin{array}{l}\text { of these: } \\
\text { manual } \\
\text { labour }\end{array}$ & $\begin{array}{l}\text { host country } \\
\text { source country } \\
\text { total region }\end{array}$ & $\begin{array}{r}-0.67 \\
0.29 \\
-0.38\end{array}$ & $\begin{array}{r}-0.54 \\
0.29 \\
-0.29\end{array}$ & $\begin{array}{r}-0.66 \\
0.45 \\
-0.35\end{array}$ & $\begin{array}{r}-0.57 \\
0.46 \\
-0.28\end{array}$ & $\begin{array}{r}-0.75 \\
0.46 \\
-0.41\end{array}$ & $\begin{array}{r}-0.57 \\
0.46 \\
-0.28\end{array}$ \\
\hline $\begin{array}{l}\text { non-manual } \\
\text { labour }\end{array}$ & $\begin{array}{l}\text { host country } \\
\text { source country } \\
\text { total region }\end{array}$ & $\begin{array}{r}-0.16 \\
0.29 \\
-0.04\end{array}$ & $\begin{array}{r}-0.13 \\
0.29 \\
-0.01\end{array}$ & $\begin{array}{r}-0.16 \\
0.45 \\
-0.01\end{array}$ & $\begin{array}{r}-0.28 \\
0.45 \\
-0.10\end{array}$ & $\begin{array}{r}-0.32 \\
0.45 \\
-0.13\end{array}$ & $\begin{array}{r}-0.28 \\
0.45 \\
-0.10\end{array}$ \\
\hline capital-owners & $\begin{array}{l}\text { host country } \\
\text { source country } \\
\text { total region }\end{array}$ & $\begin{array}{r}0.87 \\
-0.71 \\
0.42\end{array}$ & $\begin{array}{r}0.70 \\
-0.71 \\
0.30\end{array}$ & $\begin{array}{r}0.90 \\
-0.55 \\
0.51\end{array}$ & $\begin{array}{r}0.57 \\
-0.55 \\
0.26\end{array}$ & $\begin{array}{r}0.81 \\
-0.55 \\
0.44\end{array}$ & $\begin{array}{r}0.57 \\
-0.55 \\
0.26\end{array}$ \\
\hline $\begin{array}{l}\text { income of } \\
\text { migrants }\end{array}$ & & 207.13 & 145.80 & 242.49 & 167.61 & 241.75 & 167.61 \\
\hline $\begin{array}{l}\text { post-tax wages } \\
\text { manual } \\
\text { labour }\end{array}$ & $\begin{array}{l}\text { host country } \\
\text { source country } \\
\text { total region }\end{array}$ & $\begin{array}{l}- \\
-\end{array}$ & $\begin{array}{l}- \\
- \\
-\end{array}$ & $\begin{array}{r}-0.45 \\
0.39 \\
0.31\end{array}$ & $\begin{array}{r}-0.50 \\
0.39 \\
0.18\end{array}$ & $\begin{array}{r}-0.49 \\
0.39 \\
0.24\end{array}$ & $\begin{array}{r}-0.50 \\
0.39 \\
0.18\end{array}$ \\
\hline $\begin{array}{l}\text { non-manual } \\
\text { labour }\end{array}$ & $\begin{array}{l}\text { host country } \\
\text { source country } \\
\text { total region }\end{array}$ & $\begin{array}{l}- \\
- \\
-\end{array}$ & $\begin{array}{l}- \\
- \\
-\end{array}$ & $\begin{array}{l}0.04 \\
0.21 \\
0.43\end{array}$ & $\begin{array}{r}-0.24 \\
0.21 \\
0.18\end{array}$ & $\begin{array}{r}-0.10 \\
0.21 \\
0.31\end{array}$ & $\begin{array}{r}-0.24 \\
0.21 \\
0.18\end{array}$ \\
\hline & & \multicolumn{6}{|c|}{ change in \%-points at an immigration (emigration) of $1 \%$ of the labour force } \\
\hline $\begin{array}{l}\text { unemployment } \\
\text { rate }\end{array}$ & $\begin{array}{l}\text { host country } \\
\text { source country } \\
\text { total region }\end{array}$ & $\begin{array}{l}- \\
-\end{array}$ & $\begin{array}{l}- \\
-\end{array}$ & $\begin{array}{l}-0.04 \\
-0.19 \\
-0.17\end{array}$ & $\begin{array}{r}0.19 \\
-0.19 \\
-0.05\end{array}$ & $\begin{array}{r}0.06 \\
-0.19 \\
-0.12\end{array}$ & $\begin{array}{r}0.19 \\
-0.19 \\
-0.05\end{array}$ \\
\hline $\begin{array}{l}\text { manual } \\
\text { labour }\end{array}$ & $\begin{array}{l}\text { host country } \\
\text { source country } \\
\text { total region }\end{array}$ & $\begin{array}{l}- \\
- \\
-\end{array}$ & $\begin{array}{l}- \\
- \\
-\end{array}$ & $\begin{array}{l}-0.09 \\
-0.16 \\
-0.20\end{array}$ & $\begin{array}{r}0.26 \\
-0.16 \\
-0.04\end{array}$ & $\begin{array}{r}0.06 \\
-0.16 \\
-0.13\end{array}$ & $\begin{array}{r}0.26 \\
-0.16 \\
-0.04\end{array}$ \\
\hline $\begin{array}{l}\text { non-manual } \\
\text { labour }\end{array}$ & $\begin{array}{l}\text { host country } \\
\text { source country } \\
\text { total region }\end{array}$ & $\begin{array}{l}- \\
-\end{array}$ & $\begin{array}{l}- \\
- \\
-\end{array}$ & $\begin{array}{l}-0.02 \\
-0.21 \\
-0.14\end{array}$ & $\begin{array}{r}0.13 \\
-0.21 \\
-0.06\end{array}$ & $\begin{array}{r}0.05 \\
-0.21 \\
-0.10\end{array}$ & $\begin{array}{r}0.13 \\
-0.21 \\
-0.06\end{array}$ \\
\hline
\end{tabular}

GDP per capita is in the high wage region $25 \%$ above, in the low-wage region $25 \%$ below the country average. The labour force has in both regions the same size. All migrants move into the high wage region. $50 \%$ of the migrants are manual workers. For the source country the assumptions of the baseline scenario apply.

1) Clearing labour markets in the host and source country.-- 2) Clearing labour markets in high income region. The semi-elasticity between wage and unemployment rate is -0.4 and -1.0 for manual and non-manual labour, respectively, in the low-income region. In the reference case of homogeneous regions a semi-elasticity of -0.8 and -1.5 for manual and non-manual wages is assumed.-- 3 ) The semi-elasticity of manual and non-manual wages is -2.0 and -3.0 , respectively, in the high income region; for the low-income region and the reference case the same assumptions as in the previous scenario apply.

Source : Calculations of the authors. See text for further assumptions.

In the calibration of this version of the model we assume that the host country consists of two regions, and that the proportion of manual and non-manual labour is the same in each region. The income shares of the production factors are the same as in the baseline. 
Total factor productivity and the physical capital stock are 25 per cent above the country average in the high income region, and 25 per cent below in the low-income region, in line with regional income disparities in several European economies. All the remaining assumptions are as in the baseline. We assume that all (foreign) migrants move to the high-income region, and that 50 per cent of the migrants are manual workers.

Table 3.2. compares the outcomes under regional disparities with the case of homogenous regions. In particular, in the first scenario, labour markets clear in both regions of the host country and the source country. In the second scenario, labour markets clear in the high-income region, but not in the low-income region. The third scenario wage flexibility is higher in the high-income region.

The first scenario shows that the aggregate gains in GDP in the receiving country increase from 0.7 to almost 0.9 per cent, and in the total region from 0.3 to 0.4 per cent relative to the case of homogeneous regions. Moreover, the aggregate gains of the native population are more than twice as high as in the reference case. In the second scenario the gains increase even further, since under labour market clearing in the high wage regions the total unemployment rate in the receiving country is lower and labour supply in the prosperous region is larger. Under the assumption that wage rigidities are less marked in the rich region than in the poor region, there are still substantial GDP gains, but natives in the receiving country continue to experience an aggregate GDP loss. However, migration has a positive or only a small negative impact on employment (Table 3.2).

The above results rely on the assumption that the production function exhibits constant returns to scale. In presence of economies of scale at the regional level, the gains for the receiving region and country would be larger. However, there would be losses for the sending countries, due to their shrinking workforce.

Overall, regional disparities in income and employment increase the gains from migration for the enlarged EU substantially, but natives in the receiving countries can still lose out from migration if labour markets do not clear in the rich region.

\subsection{Migration and the welfare door}

The EU regulations require an equal treatment of natives and EU-migrants in terms of access to the welfare state. Member States are however allowed to protect themselves against 'welfare shopping', by restricting immigration from other EU countries if migrants cannot prove that they are able to finance their living out of work or wealth. So far intra-EU migration did not put pressure on the welfare states since unemployment and welfare dependency rates of EU-migrants are broadly in line with those of natives (Boeri, Hanson and McCormick, 2001). However, the equal treatment principle in presence of larger income differences in the enlarged EU may involve some welfare shopping by citizens of the NMS, potentially setting in motion a 'race to the bottom' in welfare provision in the enlarged EU (Sinn, 2000).

In this Section, we analyse the impact of welfare benefits on incomes of natives and migrants. According to the Roy (1952) model, a welfare state compressing the wage 
distribution by skill level will increase the inflow of low-skill workers. As migrants face a higher risk of becoming unemployed, access to welfare benefits can also increase the size of migration flows. Thus, welfare benefits affect income in the receiving countries via two channels: they do it directly, by redistributing income from the native to the migrant population, and, indirectly, by affecting the size and composition of the migrant population.

Table 3.3

Direct effect of unemployment benefits in the receiving country

\begin{tabular}{|c|c|c|c|c|c|}
\hline & \multicolumn{5}{|c|}{ unemployment benefits in \% of net wage } \\
\hline & 0 & 30 & 40 & 50 & 60 \\
\hline & \multicolumn{5}{|c|}{ change in $\%$ at an immigration of $1 \%$ of the labour force } \\
\hline $\begin{array}{l}\text { income of natives } \\
\text { of these: }\end{array}$ & -0.06 & -0.09 & -0.10 & -0.11 & -0.12 \\
\hline manual labour & -0.46 & -0.50 & -0.51 & -0.52 & -0.54 \\
\hline non-manual labour & -0.23 & -0.26 & -0.27 & -0.29 & -0.30 \\
\hline income of migrants & 126.83 & 137.14 & 140.45 & 143.68 & 146.86 \\
\hline \multicolumn{6}{|l|}{ post-tax wages } \\
\hline manual labour & -0.38 & -0.45 & -0.47 & -0.49 & -0.51 \\
\hline non-manual labour & -0.13 & -0.20 & -0.22 & -0.24 & -0.26 \\
\hline
\end{tabular}

The simulation is inter alia based in the following assumptions: (i) the unemployment is before migration 15\% and 5\% for manual and non-manual labour, respectively; (ii) the unemployment rate of migrants is twice as high as that of natives; (iii) the semi-elasticity is -1.0 and -1.5 for manual and non-manual wages, respectively; (iv) the share of manual workers in the migrant population is $50 \%$.

Source: Calculations of the authors. See text for further assumptions.

The direct impact of an increase in welfare benefits (at a given immigration level of one per cent of the labour force) is calibrated in Table 3.3. As in previous scenarios, it is assumed that unemployment benefits offer a uniform replacement rate, and are financed by a flat tax on labour income. The replacement rates vary between zero and 60 per cent of the net income. Furthermore, it is assumed that the unemployment rate of migrants is twice as high as that of natives in each segment of the labour market. The latter assumption is very pessimistic, since we observe among EU migrants similar unemployment rates than among the native population. Nevertheless, even under these pessimistic assumptions, the loss in aggregate income for natives increases from 0.06 per cent of GDP to 0.12 per cent when the replacement rate increases from zero to 60 per cent. However, the post-tax income losses for manual labour increase from 0.38 to 0.51 per cent, and for non-manual labour from 0.13 to 0.26 per cent (Table 3.3). 
Table 3.4

Total effects of unemployment benefits

\begin{tabular}{|c|c|c|c|c|c|c|}
\hline & & \multicolumn{4}{|c|}{ unemployment benefits in $\%$ of net wage } & \multirow[b]{2}{*}{60} \\
\hline & & 0 & 30 & 40 & 50 & \\
\hline \multicolumn{7}{|c|}{ ratio of expected income host/home country } \\
\hline \multirow{2}{*}{\multicolumn{2}{|c|}{$\begin{array}{l}\text { manuelle Arbeitskräfte } \\
\text { nicht-manuelle Arbeitskräfte }\end{array}$}} & 2.40 & 2.63 & 2.70 & 2.78 & 2.85 \\
\hline & & 2.16 & 2.17 & 2.17 & 2.17 & 2.18 \\
\hline \multicolumn{2}{|c|}{ size of migration (in \% of home pop.) } & 2.44 & 2.56 & 2.60 & 2.64 & 2.67 \\
\hline \multicolumn{2}{|c|}{ share of manual labour in migrant pop. } & 44.84 & 47.17 & 47.83 & 48.44 & 49.01 \\
\hline & & \multicolumn{5}{|c|}{ change in \% } \\
\hline \multirow[t]{3}{*}{ total GDP } & host country & 1.33 & 1.45 & 1.45 & 1.45 & 1.50 \\
\hline & source country & -1.35 & -1.45 & -1.45 & -1.45 & -1.52 \\
\hline & total region & 0.59 & 0.64 & 0.64 & 0.64 & 0.66 \\
\hline \multirow{3}{*}{$\begin{array}{l}\text { total income } \\
\text { natives }\end{array}$} & host country & -0.16 & -0.23 & -0.25 & -0.27 & -0.31 \\
\hline & source country & 0.39 & 0.42 & 0.42 & 0.41 & 0.44 \\
\hline & total region & -0.01 & -0.05 & -0.07 & -0.08 & -0.11 \\
\hline \multicolumn{7}{|l|}{ of these: } \\
\hline manual & host country & -0.83 & -1.14 & -1.21 & -1.27 & -1.21 \\
\hline \multirow[t]{2}{*}{ labour } & source country & 0.88 & 1.06 & 1.09 & 1.12 & 0.99 \\
\hline & total region & -0.33 & -0.51 & -0.55 & -0.59 & -0.59 \\
\hline \multirow{3}{*}{$\begin{array}{l}\text { non-manual } \\
\text { labour }\end{array}$} & host country & -0.73 & -0.77 & -0.78 & -0.79 & -0.95 \\
\hline & source country & 1.30 & 1.30 & 1.28 & 1.25 & 1.46 \\
\hline & total region & -0.20 & -0.23 & -0.24 & -0.25 & -0.31 \\
\hline \multirow[t]{3}{*}{ capital-owners } & host country & 1.33 & 1.45 & 1.45 & 1.45 & 1.50 \\
\hline & source country & -1.35 & -1.45 & -1.45 & -1.45 & -1.52 \\
\hline & total region & 0.59 & 0.64 & 0.64 & 0.64 & 0.66 \\
\hline \multirow{3}{*}{$\begin{array}{l}\text { income of } \\
\text { migrants }\end{array}$} & & & & & & \\
\hline & & 123.50 & 133.63 & 137.10 & 140.59 & 141.36 \\
\hline & & \multicolumn{5}{|c|}{ change in \%-points } \\
\hline \multirow{3}{*}{$\begin{array}{l}\text { unemployment } \\
\text { rate }\end{array}$} & host country & 0.46 & 0.50 & 0.50 & 0.50 & 0.52 \\
\hline & source country & -0.45 & -0.49 & -0.49 & -0.49 & -0.51 \\
\hline & total region & -0.06 & -0.06 & -0.06 & -0.06 & -0.06 \\
\hline \multirow{3}{*}{$\begin{array}{l}\text { manual } \\
\text { labour }\end{array}$} & host country & 0.49 & 0.59 & 0.61 & 0.62 & 0.56 \\
\hline & source country & -0.30 & -0.37 & -0.38 & -0.40 & -0.34 \\
\hline & total region & 0.00 & 0.00 & 0.00 & 0.00 & 0.01 \\
\hline \multirow{3}{*}{$\begin{array}{l}\text { non-manual } \\
\text { labour }\end{array}$} & host country & 0.42 & 0.40 & 0.39 & 0.38 & 0.47 \\
\hline & source country & -0.63 & -0.63 & -0.61 & -0.60 & -0.71 \\
\hline & total region & -0.11 & -0.12 & -0.12 & -0.12 & -0.12 \\
\hline
\end{tabular}

The scale of migration and the share of manual workers in the migrant population is determined endogeneously.--

The simulation is inter alia based in the following assumptions: (i) the unemployment is before migration

$15 \%$ and $5 \%$ for manual and non-manual labour, respectively; (ii) the unemployment rate if migrants is twice

as high as that of natives; (iii) the semi-elasticity is -1.0 and -1.5 for manual and non-manual wages, respectively.

Source: Calculations of the authors. See text for further assumptions.

In Table 3.4. we allow the level of welfare benefits to affect also the size and composition of migration flows applying realistic assumptions as to the elasticity of migration with respect to the income differential. In particular, following Harris and Todaro (1970) we assume that jobs are allocated in each period by a random draw among the labour force, but that the risk of being unemployed is twice as high for migrants than for natives. Since foreign workers face a higher risk of unemployment, incentives to migrate, notably among the low-skilled, increase with the replacement rate.

The number of migrants increases from slightly more than 2.4 per cent of the source population to almost 2.7 per cent when the replacement rate increases from zero to 60 per cent, i.e. by less than 0.3 percentage points. The share of manual workers in the migrant population also increases from 45 per cent to 49 per cent, i.e. by no more than 4 
percentage points. Both the GDP in the receiving country and in the enlarged EU increase with the replacement rate. This is due to the fact that a higher level of welfare benefits increases the incentives to migrate for everybody, not only for those who become later on recipients of unemployment benefits. Larger migration flows generate a higher income level via a more efficient allocation of labour. The unemployment rate increases in the receiving country, but falls in the enlarged EU with the replacement rate because unemployment is higher in the source region. Finally, the aggregate income of natives falls with the replacement rate in the receiving countries.

Thus, the scenario with unemployment benefits increases the conflict of interests between the enlarged EU and the receiving countries. Under realistic assumptions about unemployment rates of the migrant population, an increase in welfare benefits raises income in the total region. This counter-intuitive results stems from the fact that higher welfare benefits increase also the incentives for to migrate for those who will work in the receiving countries. In contrast, the income of natives in the receiving countries will fall with increasing welfare benefits. However, under a realistic range for the replacement rate (between 40 and 60 per cent of post-tax wages), the income losses for the native population from additional welfare payments and changes in the scale and composition of the migrant population are rather small.

\subsection{Does migration substitute FDI and other capital movements?}

The transition to a market economy in the CEECs triggered substantial capital flows to the region. The overwhelming share of these capital flows are foreign direct investments (FDI), ranging between 10 and 24 billion Euros per year, while the inward FDI stock amounted to 142.2 billions in $2003 .^{13}$ It is difficult to predict the sign of the effects, if any, of migration on these FDI flows. 'Vertical' FDIs are motivated by differences in factor endowments and factor prices, while 'horizontal' FDIs are driven by market access and the exploitation of scale economies. ${ }^{14}$ Empirical estimates of FDIs include therefore variables related to the market size (e.g. aggregate GDP) as well as measures of differences in factor endowments (e.g. differences in GDP per capita or skill endowments) (Carr et al., 2001; Blonigen et al., 2003; Geishecker and Görg, 2005). Migration can negatively affect FDIs by increasing wages and per capita GDP levels in the sending countries. The effect of migration on horizontal FDIs is less predictable because migration, on the one hand, increases the size of markets in the immigration country, hence factor incomes in the enlarged EU, but, on the other hand, reduces the size of the market in the sending country, hence, the incentives to invest therein. The empirical literature does not provide guidance as to which of these different effects is likely to prevail (see Annex B.5).

\footnotetext{
${ }^{13}$ Hunja (2005), based on the balance of payments statistics of the National Banks.

${ }^{14}$ See Markusen (1984) and Markusen and Venables (1998) for vertical models, and Helpman (1984) and Helpman and Krugman (1985) for horizontal models of multinational firms.
} 
Table 3.5

The impact of capital movements

\begin{tabular}{|c|c|c|c|c|c|c|}
\hline \multirow{2}{*}{\multicolumn{2}{|c|}{$\begin{array}{l}\text { semi-elasticity between } \\
\text { wage and unemployment rate } \\
\text { manual labour } \\
\text { non-manual labour }\end{array}$}} & \multirow{2}{*}{$\begin{array}{r}\begin{array}{c}\text { clearing } \\
\text { labour markets }\end{array} \\
\begin{array}{l}\text {-infinity } \\
\text {-infinity }\end{array}\end{array}$} & \multirow{2}{*}{$\begin{array}{r}\text { fixed manual } \\
\text { wages } \\
0 \\
\text {-infinity }\end{array}$} & \multicolumn{3}{|c|}{$\begin{array}{l}\text { rigid wages of manual } \\
\text { and non-manual labour }\end{array}$} \\
\hline & & & & $\begin{array}{l}-0.4 \\
-1.0\end{array}$ & $\begin{array}{l}-1.0 \\
-1.5\end{array}$ & $\begin{array}{l}-1.5 \\
-3.0\end{array}$ \\
\hline \multirow{4}{*}{ total GDP } & & \multicolumn{5}{|c|}{ change in $\%$ at a movement of $1 \%$ of Western capital } \\
\hline & West & -0.32 & -0.32 & -0.32 & -0.31 & -0.30 \\
\hline & East & 3.79 & 3.79 & 4.68 & 4.03 & 3.58 \\
\hline & total region & 0.84 & 0.80 & 1.05 & 0.88 & 0.76 \\
\hline \multicolumn{7}{|l|}{ income of } \\
\hline manual & West & -0.28 & -0.28 & -0.29 & -0.29 & -0.29 \\
\hline labour & East & 2.56 & 2.50 & 4.27 & 3.83 & 3.34 \\
\hline & total region & 0.58 & 0.51 & 1.01 & 0.88 & 0.74 \\
\hline \multirow{3}{*}{$\begin{array}{l}\text { non-manual } \\
\text { labour }\end{array}$} & West & -0.36 & -0.36 & -0.34 & -0.32 & -0.32 \\
\hline & East & 4.77 & 4.71 & 4.98 & 4.18 & 3.76 \\
\hline & total region & 1.02 & 0.99 & 1.08 & 0.88 & 0.77 \\
\hline \multirow[t]{3}{*}{ capital-owners } & West & -0.32 & -0.32 & -0.32 & -0.31 & -0.30 \\
\hline & East & 3.79 & 3.79 & 4.68 & 4.03 & 3.58 \\
\hline & total region & 0.84 & 0.80 & 1.05 & 0.88 & 0.76 \\
\hline \multicolumn{7}{|l|}{ post-tax wages } \\
\hline manual & West & -0.23 & -0.23 & -0.26 & -0.27 & -0.27 \\
\hline \multirow[t]{2}{*}{ labour } & East & 1.37 & 1.32 & 3.13 & 3.11 & 2.83 \\
\hline & total region & -0.60 & -0.70 & -0.16 & 0.14 & 0.21 \\
\hline \multirow{3}{*}{$\begin{array}{l}\text { non-manual } \\
\text { labour }\end{array}$} & West & -0.36 & -0.36 & -0.34 & -0.32 & -0.31 \\
\hline & East & 3.79 & 3.79 & 2.46 & 2.51 & 2.73 \\
\hline & total region & 1.02 & 0.93 & 0.44 & 0.43 & 0.50 \\
\hline & & change in \% & oints at a moven & of $1 \%$ of & stern c & \\
\hline \multirow{3}{*}{$\begin{array}{l}\text { unemployment } \\
\text { rate }\end{array}$} & West & - & 0.04 & 0.04 & 0.02 & 0.02 \\
\hline & East & - & -1.34 & -2.20 & -1.43 & -0.92 \\
\hline & total region & - & -0.65 & -1.08 & -0.70 & -0.45 \\
\hline \multirow{3}{*}{$\begin{array}{l}\text { manual } \\
\text { labour }\end{array}$} & West & - & 0.11 & 0.08 & 0.05 & 0.04 \\
\hline & East & - & -2.68 & -2.55 & -1.59 & -1.14 \\
\hline & total region & - & -1.44 & -1.39 & -0.86 & -0.62 \\
\hline \multirow{3}{*}{$\begin{array}{l}\text { non-manual } \\
\text { labour }\end{array}$} & West & - & - & 0.01 & 0.00 & 0.00 \\
\hline & East & - & - & -1.84 & -1.26 & -0.70 \\
\hline & total region & - & - & -0.83 & -0.57 & -0.32 \\
\hline
\end{tabular}

Source: Calculations of the authors. See text for assumptions.

FDI itself can substitute for migration. Table 3.5 presents scenarios in which we allow a sizeable flow of the capital stock to flow from the West to the East (1 per cent of the capital stock in the West corresponding to 1 per cent in the East). We assume that 50 per cent of the migrants are manual workers and that wages are responsive not only to unemployment, but also to changes in capital endowments. In particular, the semielasticity of the wage of manual workers with respect to an increase in the capital stock is 0.2 , and that of non-manual workers is 0.3. Under these assumptions, the capital flow increases total GDP in the enlarged EU by 0.8 to 1 per cent. The aggregate gains are larger under rigid labour markets, as unemployment is higher in the East than in the West. Wages fall in the host country by around 0.3 per cent, and the unemployment rate increases slightly by $0.02-0.004$ percentage points. In the East a substantial increase in GDP (between 3.8 and 4.7 per cent) is observed, together with a drop in the unemployment rate by 0.9-2.2 percentage points, and an increase in wages by 1.4-3.8 per cent. 
We analyse the interaction between migration and FDI in two scenarios. In the first scenario, we allow migration of 1 per cent of the population in the East to affect, via its impact on GDP and GDP per capita, the scale of FDIs and we evaluate the overall impact including this second round effect of the change in FDIs on income and employment. In the second scenario, we analyse how the capital flow described above affects the size of migration flows, and again second round effects. The scale of FDI is determined by an empirical estimation of FDI-stocks (Görg and Geishecker, 2005) which is motivated by the capital-knowledge model (Markusen, 2002) ${ }^{15}$. FDI stocks are explained, inter alia, by the joint GDP of the two countries, the difference in their aggregate GDP and the difference in GDP per capita (See Appendix B.5. for details)

Table 3.6 shows that the impact of migration on capital flows is negligible. Under reasonable assumptions on wage rigidities, the migration of 1 per cent of the labour force increases GDP in the receiving country by 0.56 per cent, reduces it in the sending country by 0.55 per cent, and increases at in the total region by 0.25 per cent (see Table 3.1). According to our simulations, this reduces the net investment from the West in the East by no more than 27 million Euros. As a consequence, the second round effects of migration via FDI are (almost) negligible.

The picture changes considerably when we consider the reverse type of interaction, from FDIs to migration. A flow of 1 per cent of the capital stock from the West to the East increases the GDP in the East by 4.3 per cent and reduces it in the West by 0.3 per cent (see Table 3.5). This reduces migration by 0.13 per cent of the labour force and the potential GDP gains from migration by 0.07 per cent (Table 3.6).

Thus, while we there is almost no substitution of capital movements by migration, capital movements can substitute for migration. This asymmetry can be explained by the relative size of the capital flows posited in our scenarios (a 10 per cent increase in the capital stock in the East!) and the fact that the impact of migration on capital movements is ambiguous, while capital inflows increase GDP and wages in the receiving country and therefore unambiguously reduce incentives to migrate.

\footnotetext{
15 The "knowledge-capital-model" by Markusen (2002) provides a hybrid framework in which both vertical and horizontal FDIs emerge endogenously, depending on the characteristics of the home and the foreign country.
} 
Table 3.6

Substitutional effects of migration and FDI

\begin{tabular}{|c|c|c|c|}
\hline & & effects of & ent of $1 \%$ of \\
\hline & & workforce in the East & capital stock in the West \\
\hline & & & \\
\hline capital stock & West & -0.001 & - \\
\hline & East & 0.007 & - \\
\hline total labour force & West & - & -0.13 \\
\hline & East & - & 0.13 \\
\hline & & effect & ution of \\
\hline & & capital movents & migration \\
\hline & & & \\
\hline total GDP & West & 0.00 & -0.07 \\
\hline & East & -0.04 & 0.07 \\
\hline total income & West & 0.00 & 0.02 \\
\hline natives & East & -0.04 & -0.02 \\
\hline of these: & & & \\
\hline manual & West & 0.00 & 0.07 \\
\hline labour & East & -0.03 & -0.06 \\
\hline non-manual & West & 0.00 & 0.04 \\
\hline labour & East & -0.04 & -0.06 \\
\hline capital-owners & West & 0.00 & -0.07 \\
\hline & East & -0.04 & 0.07 \\
\hline & & cha & oints \\
\hline unemployment & West & 0.00 & -0.02 \\
\hline rate & East & 0.02 & 0.02 \\
\hline manual & West & 0.00 & -0.03 \\
\hline labour & East & 0.03 & 0.02 \\
\hline non-manual & West & 0.00 & -0.02 \\
\hline labour & East & 0.02 & 0.03 \\
\hline
\end{tabular}

Source : Calculations of the authors. See text for further assumptions.

\section{PERCEPTIONS AND CROSS-COUNTRY DIFFERENCES IN MIGRATION RESTRICTIONS}

\subsection{How to read our results}

The back-of-the-envelope calculations presented in the previous section provide of course no more than a hint to the actual magnitudes involved, and a number of important caveats apply.

First, we have ignored the interactions between migration and trade. Analogously to capital movements, migration can be a substitute or a complement to trade. If migration is a substitute for trade, then its effects on wages and unemployment are likely to be smaller.

Second, we have neglected the accumulation of physical and human capital. The effects of a one-term shock in labour supply diminish however over time in the course of capital accumulation, since the economy will eventually achieve the same factor proportions as before the shock. Our results have therefore only a short-run character, 
they disappear over time. Nevertheless, under realistic assumptions on the convergence of capital stocks to their steady state values, the impact of migration can be felt for rather long time periods. Our findings are consistent with results from more complex CGE models, which rely on an open economy framework and consider capital accumulation. However, econometric studies find a smaller, if any, impact of migration on wages and employment than in our scenarios. The latter should therefore be interpreted as an extreme (pessimistic) characterisation of the labour market effects of migration in the receiving countries (Box 5).

\section{Box 5 Evidence from other studies}

The results of our simulation model can overstate the actual impact of migration since the accumulation of physical and human capital are ignored. Moreover, the possible substitution of trade through migration is not considered by our model. It is therefore instructive to confront our results with the findings from more complex simulation models which are based on an open-economy framework and which also include the dynamic effects of migration. There exist meanwhile a number of studies which have calibrated the impact of Eastern Enlargement on GDP, wages and employment in complex computable equilibrium models. Keuschnigg and Kohler (1999) assess the impact of Eastern Enlargement on Austria in an open-economy CGE-model, assuming inter alia that the number of unskilled workers increase by 10.5 per cent and the number of skilled workers by 2.1 per cent. As a result, the wages for unskilled workers drop by 5 per cent and those of skilled workers increase by 2.7 per cent, i.e. the respective elasticities are similar to those we have found if we consider that our simulations are based on a one per cent increase. Heijdra et al. (2002) calibrate the effects of migration, trade and fiscal transfers for national welfare in an open-economy CGE model, and find inter alia that migration in the context of enlargement increases the German GDP by 0.7 per cent. Given that the simulation relies on the assumption that the manual-labour force increases by 6.2 per cent and the non-manual labour force by 0.8 per cent, this result is slightly below our estimates. In another study Kohler (2002) finds overall GDP gains from migration in the context of Eastern Enlargement of 1.2 per cent for Germany, using the same migration scenario as the study as Hejdra et al. (2002). Thus, the GDP effect is here slightly higher than in our projections. Finally, Brücker and Kohlhaas (2004) have simulated the impact of migration for Germany in a CGE-model employing different assumptions on the education levels of the migrant population. They find that, depending on the assumptions on the qualification of the migrant population, that wages can decline by 0.5 to 0.6 per cent at an immigration of one per cent of the labour force, while the unemployment rate increases by 0.02 to 0.1 percentage points. Again, these results are in the range of our findings. Altogether, although more complex CGE-models allow to capture both the dynamic effects of migration and its affects on the structure of production and trade, they yield very similar results as our simple simulation model.

The labour market impact of migration has been furthermore examined in a large number of econometric studies in Europe. These studies rely on a cross-section of either regions or branches, and use variations in the migrant density in order to identify the impact of migration on wages and employment. This approach suffers from various methodological problems, inter alia it is hard to control for the fact that migrants tend to move into prosperous regions or industries. The empirical results depend therefore heavily on the methods by which it is controlled for this endogeneity problem. Nevertheless, in particular the more recent studies in Europe find much smaller wage and employment effects that our simulation results suggest (see e.g. Winter-Ebmer and Zweimüller, 1996; Bauer 1997; Gavasto et. al. 1999; Trabold and Trübswetter, 2003; Brücker, 2002 for a review). This could be interpreted as support for the hypothesis that the open-economy framework is more appropriate to analyse the economic effects of migration than the closed economy framework. Indeed, Hanson and Slaughter (2002) find evidence for the existence of Rybczyinski-effects in the US. The view that migration is neutral for wages and employment of natives in the receiving countries has been recently challenged by George Borjas (2003), who finds wage effects which are similar to those in our simulation exercise in an econometric study which refers to changes in the factor proportions at the national level.

Thus, given the controversial empirical evidence, we can conclude that our simulations form a bottomline with respect to the wage and employment of migration in the receiving countries, the actual impact 
can also be much moderate or even neutral. Nevertheless, given the uncertainty on the wage and employment impact of migration, incentives for a closing-the-door-policy remain in the receiving countries.

Third, we considered only legal migration. A closing-the-door immigration policy implies that illegal migration increases at the expense of legal migration. In contrast, opening the labour market and the welfare door creates incentives for illegal migrants to move into the regular labour market. This in turn generates - relative to the state of illegal migration -benefits for the public sector and the total economy in the receiving countries. This is particularly relevant in the case of Eastern Enlargement, where a substantial number of illegal migrants work already in the neighbouring countries.

Fourth, the analysis of the impact of migration on the welfare state has been limited to unemployment benefits. The fiscal balance of migration is however affected also by a number of other factors. Pension schemes are here particularly relevant, since the pensions of migrants fall short of their contributions in most EU countries. Depending on pension systems and other welfare institutions, the fiscal effects of migration can turn to be positive, even if they are more than proportionally affected by unemployment. $^{16}$

Overall, the simulations provided in the previous section neglect a number of factors which could alleviate or even change the sign of the economic effects of migration on the receiving country. Nevertheless, insofar as they suggest that receiving countries may also lose out from immigration, they are useful in understanding concerns of public opinion in the EU-15. This in turn can improve our understanding of the evolution of migration policies in the EU discussed in Section 1. Below we first relate our predictions as to the economic costs of migration to perceptions of public opinion and then we assess whether reforms in migration policies are driven by these concerns of public opinion (internal pressure) or by the spillover effects of decisions made in other countries (external pressure), notably the fear that the diversion effects, documented in Section 2 in the case of Enlargement, could materialise.

\subsection{What drives the tightening of migration policies?}

Section 2 suggests that migration policies entail substantial spillover effects, while Section 3 points to short-term costs of migration in rigid labour markets, possibly inducing public opinion to support restrictive migration policies.

Which one of these factors - the fear of a potential diversion of migration flows or the perception of the economic costs of migration - has been behind the tightening of migration restrictions occurred in the last decade? In order to answer this question it is necessary to proceed in two steps. We first analyse whether the costs characterised in the previous section do play indeed an important role in shaping preferences for

\footnotetext{
${ }^{16}$ As an example, Bonin et al. (2000) and Löffelholz and Köpp (1998) find substantial positive effects for Germany, while Sinn et al. (2001) conclude that the impact is negative. For the Netherlands, which has another pension system than Germany, Roodenburg et al. (2003) find negative effects using the same approach as Bonin et al. (2000) for Germany.
} 
migration. Next, we look at migration policy developments against the background of these perceptions and of policies in other countries.

The nature and evolution over time of preferences for migration policies in Europe can be best characterised by drawing on the Eurobarometer, a public opinion survey carried out by Gallup for the European Commission since 1970. The Eurobarometer covers the EU-15 countries and includes a number of questions about migration and policy coordination, which are repeated in different waves, although regrettably the survey does not have a longitudinal structure.

In order to assess preferences of Europeans concerning migration policy we follow a two-step procedure. At first we isolate the role played by personal characteristics in shaping preferences. Next we investigate the correlation of the residual cross-country dispersion in opinions with economic variables which are likely to affect, in light of the analysis in the previous section, support to more restrictive policies.

Table 4.1.

The role played by personal characteristics in shaping preferences for migration policies

(Eurobarometer, 1994, 1997 and 2000)

\begin{tabular}{|c|c|c|c|c|c|c|c|c|c|}
\hline & \multicolumn{3}{|c|}{ There are too many migrants } & \multicolumn{3}{|c|}{$\begin{array}{l}\text { Migrants increase } \\
\text { unemployment }\end{array}$} & \multicolumn{3}{|c|}{ Migrants abuse welfare } \\
\hline & 1994 & 1997 & 2000 & 1994 & 1997 & 2000 & 1994 & 1997 & 2000 \\
\hline male & + & & & & ++ & + & ++ & + & ++ \\
\hline $15-24$ & - & - & -- & & - & - & - & - & -- \\
\hline $25-34$ & - & - & & & - & & - & - & \\
\hline $55-64$ & & ++ & + & ++ & + & & ++ & & \\
\hline $\begin{array}{l}\text { over } 64 \\
\text { household family }\end{array}$ & + & + & & $\begin{array}{c}++ \\
+\end{array}$ & & & ++ & - & \\
\hline low-edu & & & ++ & & & ++ & & & \\
\hline high-edu & -- & -- & -- & -- & -- & -- & -- & - & -- \\
\hline right-wing & ++ & ++ & ++ & ++ & ++ & ++ & ++ & ++ & ++ \\
\hline left-wing & -- & -- & -- & -- & -- & -- & -- & -- & -- \\
\hline $\begin{array}{l}\text { employed } \\
\text { self-employed }\end{array}$ & + & & ++ & & & & & ++ & ++ \\
\hline retired & & & ++ & & & + & & ++ & ++ \\
\hline high-income & ++ & - & & ++ & - & - & & -- & - \\
\hline low-income & $\ldots$ & & - & - & & - & - & & - \\
\hline
\end{tabular}

Table 4.1. summarises results from probit regressions of various questions elicting preferences for restrictive migration policies which have been repeated at different survey dates. In particular, they concern perceptions that the "boat is full", that is, there are already "too many migrants", that "migrants increase unemployment" and that "migrants abuse of the welfare system". Personal characteristics include age, gender, education and labour market status as well as ideological (left or right-wing) factors. We also control for the characteristics of the household (number of components). Including country-dummies in these regression we explain between 12 and 16 of the total variance. Without country dummies we could explain only about 3 to 5 per cent of the total variation. The reference individual is a middle-income woman aged 35 to 54 , with a secondary educational attainment, unemployed, and located at the centre of the political spectrum. 
Unsurprisingly we find that migration is perceived as a threat mainly among older (hence immobile) men, and with low levels of education. This is consistent with the findings of previous work on preferences over immigration policy (Scheve and Slaughter, 2001; Boeri et al., 2002; Mayda and Rodrik, 2001 and O’Rourke, 2003) as well as with the distribution of losses characterised in the previous section. We also observe that political affiliation to the right increases negative perceptions about migrants.

In the second stage we aim at explaining the residual cross-country variation in terms of aggregate variables which, according to our simulations, should affect the overall perceptions about migration in a specific country. One of these variables is represented by the scale of redistributive policies. The previous section suggests that migration may be a fiscal burden in countries with relatively generous welfare systems. Dynamic political-economic model of migration -- e.g., Benhabib (1996) and Dolmas and Huffman (2003) - also indicate that support to migration could be lower in countries where redistributive policies are more important. Part of these effects should also come indirectly, via changes in the composition of migration flows, notably an increase in the share of low-skilled migrants. Thus we include the fraction of migrants with lower levels of education, as measured by the European Labour Force Survey. Also in this case, our predictions are consistent with economic theory: Razin, Sadka and Swagel (2002), extending Metzler and Richard (1981), as well as Hassler et al. (2002) suggest that it is the percentage of low-skill types among migrants to negatively affect decisions about the acceptability of migrants. In light of the results in the previous section, we also expect to find more negative perceptions of migration in countries with labour market "rigidities", such as a high coverage of collective bargaining and relatively generous replacement rates for their unemployment benefits.

Results should be interpreted with caution due to the limited degrees of freedoms and measurement errors. They suggest that negative perceptions of migrants are larger in countries with a more generous social welfare system and with more "rigid" wage setting institutions. This seems to indicate that it is indeed the type of economic costs of migration assessed in the previous section which affect preferences for migration policies. 
Table 4.2

Explaining (conditional) cross-country differences in perceptions

\begin{tabular}{lc}
\hline \hline & $\begin{array}{c}\text { Dependent variable: country-dummies in } \\
\text { regression of the toomany question }\end{array}$ \\
\hline Social policy expenditure & 0.05 \\
& $(0.01)^{* * *}$ \\
\% of high edu migrants & -0.00 \\
& $(0.01)$ \\
Coverage of coll.bargaining & 0.53 \\
& $(0.19)^{* * *}$ \\
UB rrate & -0.01 \\
& $(0.00)^{*}$ \\
constant & -2.21 \\
& $(0.55)^{* * *}$ \\
\hline Observations & 38 \\
R-squared & 0.62 \\
\hline \hline eendent variables are country fixed-effects estimated in the first stage regressions \\
ard errors in parentheses \\
ificant at 10\%; $*$ significant at 5\%; *** significant at 1\% \\
Eurobarometer 37 (1992), 41.1 (1994), 47.1 (1997), 53 (2000) \\
Eurostat for data on social expenditure, Oecd for data on union coverage and \\
replacement rate of unemployment benefits
\end{tabular}

Overall, perceptions about migrants are broadly in line with the implications of our model as to the economic costs of migration. This holds both for the within-country distribution of benefits and losses (it is mainly the low-skilled to fear job and fiscal competition from migrants) and for the cross-country differences (where countries with a richer welfare state and rigid wages display a public opinion less favourable to migrants).

The above does not imply that policies are driven by domestic public opinion. In order to characterise the determinants of the tightening of migration policies occurred in the last decade we need to compare cross-country differences in the evolution of the policy stance towards migrants to i) changes in public opinion about migrants, and ii) the policy stance in neighbouring countries. This is done in Table 4.3 which displays, in the first two columns on the left-hand-side measures of the evolution of policies, notably the net number of restrictive reforms of migration policies and the change in the value of the migration policy index introduced in Section 2. The next two columns display the 1992-2000 or 1994-2000 (1992 was in the middle of a recession) variation in the percentage of respondents who agree with the statement that there are already "too many migrants". Finally, the last two columns on the right-hand-side of Table 4.3. measure the source of potential policy spillover effects, namely the cumulative number and sign of reforms in bordering countries (border) and the overall number of reforms in the EU weighted by distance of each country from the country's capital (distance).

Two facts are important. First, migration policy have been tightened in most countries just while public opinion was becoming more favourable to migrants. Indeed, the simple and Spearman rank correlation coefficients between any of the first two columns and the third or fourth column are negative and often statistically significant. Second the evolution in each individual country is more in line with developments in other countries, especially bordering countries. Correlation coefficients are in this case positive and statistically significant. 
Table 4.3

Internal and external pressures and immigration policy reforms

\begin{tabular}{lllllll}
\hline & Reforms & $\Delta$ index & $\begin{array}{l}\Delta \text { too many } \\
(1992-2000)\end{array}$ & $\begin{array}{l}\Delta \text { too many } \\
(1994-2000)\end{array}$ & $\begin{array}{l}\text { Spillover } \\
\text { (border) }\end{array}$ & $\begin{array}{l}\text { Spillover } \\
\text { (distance) }\end{array}$ \\
\hline Austria & 2 & 0.29 & & & 3 & 2.09 \\
Belgium & 2 & & 0.5 & -3.7 & 5 & 2.51 \\
Denmark & 2 & 0.43 & -11.1 & -4.6 & 2 & 2.37 \\
Finland & 1 & 0.43 & & & 2 & 1.89 \\
France & 1 & -0.21 & -10.9 & -13.0 & 7 & 2.55 \\
Germany & 0 & 0.07 & -12.2 & -4.7 & 16 & 2.69 \\
Greece & 0 & 0.27 & 12.3 & -4.7 & 2 & 1.24 \\
Ireland & 3 & -0.14 & 19.3 & 21.0 & 1 & 2.06 \\
Italy & 1 & 0.14 & -24.4 & -15.6 & 6 & 1.85 \\
Netherlands & 1 & 0.27 & -8.3 & 0.4 & 5 & 2.72 \\
Luxemburg & 0 & 0.07 & -3.0 & 1.6 & 7 & 2.91 \\
Portugal & -1 & 0.07 & 5.4 & 10.4 & -2 & 1.47 \\
Spain & 0 & -0.37 & -0.7 & -6.3 & -2 & 1.64 \\
Sweden & 1 & & & & 6 & 2.2 \\
UK & 5 & 0.56 & -14.7 & -11.2 & 16 & 1.8 \\
\hline
\end{tabular}

Notes:

Reforms adds up reforms in immigration policy carried out in any country between 1996 and 2004.

Reforms tightening rules are entered with a positive sign and reforms making it easier access to migrants

with a negative sign. Hence a positive number signals a tightening of the immigration policy stance.

$\Delta$ index tabulates the changes in the value of the immigration policy index defined in section 1 between 1994 and 2004.

$\Delta$ too many: variation in the percentage of respondents stating that there are "too many migrants" in the 1992 and 2000 waves of the Eurobarometers or in the period 1994-2000.

Spillover (border) Counts reforms in bordering countries in the period 1996-2004.

Spillover (distance) Counts reforms in all the other countries weighted by the distance from the capital of that country.

\subsection{Do citizens accept to co-ordinate policies?}

The above suggests that policy spillovers may be relevant and hence co-ordination in migration policies may have the potential to induce less restrictive policies. But are Europeans ready to delegate power to supra-national authorities in the field of international migration? 


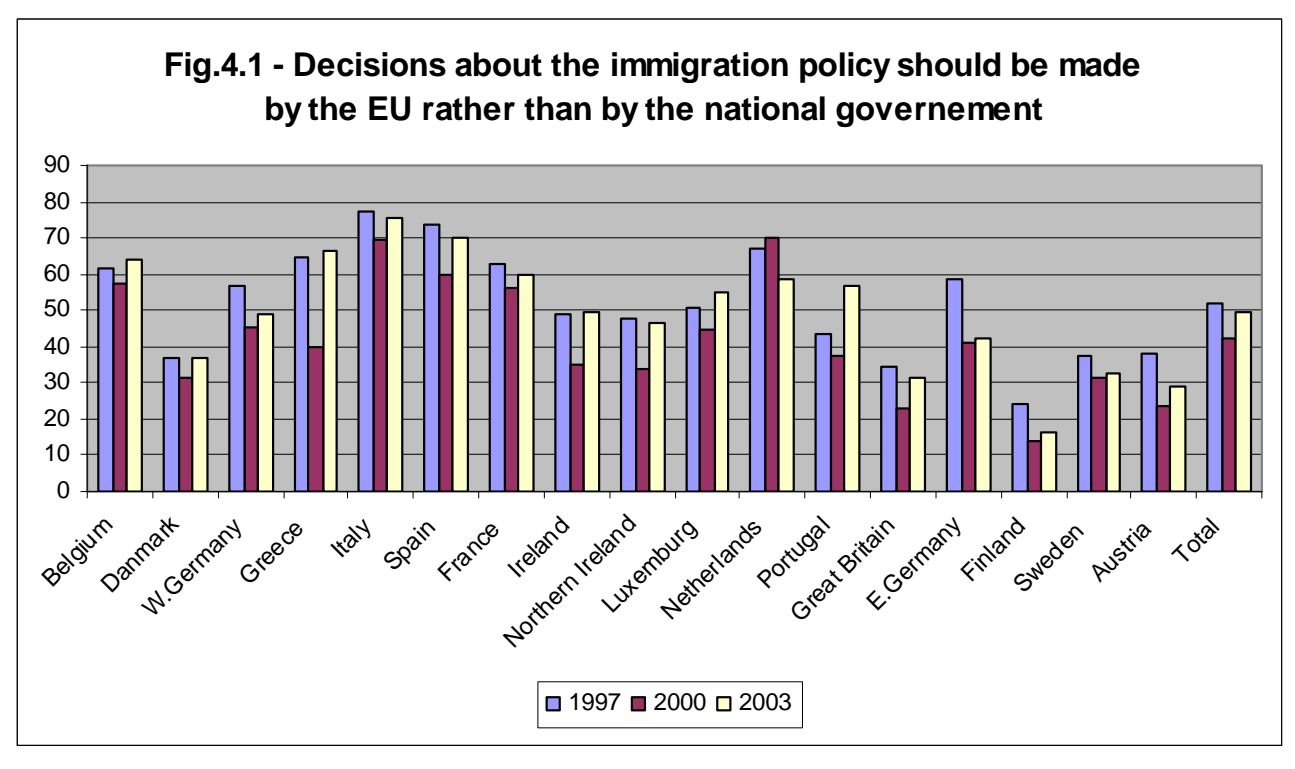

Figure 4.1. displays the percentage of individuals who are in favour of delegating authority to the EU in the field of migration policies ${ }^{17}$. Although support to policy coordination slightly declined over time and there is a high degree of heterogeneity in the answers from country to country, in most countries there is still a majority favourable to delegating authorities to Brussels in this respect. Thus, the main obstacles to policy coordination may not from citizens, but from domestic politicians who can be induced to use migration as a scapegoat to gather more votes in the elections.

It should also be stressed that policy co-ordination may itself contribute to reduce the cross-country heterogeneity in willingness to delegate authority, which is highlighted by Figure 4.1. This is because co-ordinated policies may reduce distortions in the allocation of migrants. To give an example, Tranaes and Zimmermann (2004) found that migrants to Denmark are less skilled and less likely to work than in Germany. These differences in the composition of migrants can be a by-product of migration policy itself or of other institutional features, e.g., the generosity of redistributive policies. The fact that Denmark recently reformed its own regulations by rewarding more skilled migration suggests that in the mind of policy-makers, if not of citizens themselves, a better migration policy can deliver better educated workers. Put another way, it may not be that Danes are against any type of policy co-ordination because they have different preferences about migration than other Europeans, but simply that Danes fear that a EU-policy would be different from the one that they have just adopted, and presumably believe that it is a good policy.

\section{HOW TO CO-ORDINATE THEN? FINAL REMARKS}

In this paper we analysed the economic consequences of uncoordinated immigration policies taking as reference the Eastern Enlargement episode. Economic gains from

${ }^{17}$ Citizens are asked whether or not they agree with the statement that "Decisions about immigration policy should be made by the EU (vs. the national Government). 
international migration are bound to be high, presumably higher than those from the further integration of goods and capital markets. However, while the removal of barriers to trade and capital movements gained momentum during the last two decades, we noticed a tightening of migration restrictions, most notably in Europe where regional labour mobility is low, hence there are even larger potential gains from migration. Migration barriers of the individual Member States vis-à-vis non-EU and non-EEA countries were tightened in recent years and the break-down of the Berlin wall and the fall of the iron curtain in Eastern Europe did not fundamentally altered this picture. Emigration barriers in the East have been replaced by immigration barriers in the West, so that East-West legal migration has been so far rather moderate. Moreover, free labour mobility from the NMS has been postponed for up to 7 years, as potential destination countries engaged in a 'race-to-the-top' of barriers to migration of workers from the NMS. These "transitional arrangements" carry with them substantial economic costs. Available information reviewed in this paper suggests that migration flows from the East have been diverted towards the countries which have partially opened their labour markets and that the overall level of East-West migration falls short of its potential, likely due to these restrictions.

These restrictions entail substantial economic losses for the enlarged EU. Under realistic assumptions about the convergence of GDP and wage levels, we estimated that migration to the West of 1 per cent of the population in the NMS increases the aggregate GDP in the sending and receiving countries by 0.2 to 0.3 per cent. We also expect the impact of migration on East-West capital flows to be weak. Given that trade and capital movements will equalise income and wage levels only in the long-run, the economic losses associated with migration restrictions are not of a second order of magnitude in a stagnating Europe.

Why are then Governments closing the door to migrants? This paper suggests that there are potentially two co-ordination failures behind this outcome. The first is a lack of coordination across countries receiving the migrants. The second involves the relation between sending and recipient countries.

The stylised representation of the benefits and costs of migration offered in Section 3 sheds some light on the reasons for the first type of co-ordination failures. Under realistic assumptions about wage rigidities in the labour markets of the receiving countries, international migration may actually result, at least temporarily, in a net aggregate loss in the country of destination. These losses are mitigated if we assume that regional disparities in wage and employment opportunities exist and that migrants exploit these opportunities, "greasing the wheels" of Western labour markets. Other factors increasing the benefits of immigration in the West can be trade (when the marginal demand for labour is determined by tradable sectors) and improvements in social security associated with inflows of younger cohorts of workers. Nevertheless, insofar as citizens in the West perceive a risk that immigration can be harmful, they will induce Government to close borders. We showed in this paper that negative perceptions about migration are in line with the predictions of our model as to those factors which can increase the cost of immigration in the West. In particular, negative perceptions are stronger in countries receiving many low-skilled workers, having a rather generous welfare state and rigid labour markets. However, these factors cannot explain the trend in migration policies. These "rigid" institutional features are being - albeit gradually -- 
relaxed in the West just while migration restrictions are getting tighter. And indeed the tightening is occurring even in countries where public opinion is getting over time more favourable to migrants. The trend in migration policies can be better explained by spillovers across jurisdictions, namely the fear that the closing of borders in neighbouring countries could entail a substantial diversion of flows.

How can these spillovers be internalised by policy co-ordination at the EU-level? What type of migration restrictions, if any, should be defined at the EU level?

A number of scholars, including Hans-Werner Sinn, have been recently advocating a policy closing temporarily the welfare door to migrants in the enlarged EU. Welfare access by migrants involves some (rather modest) fiscal losses in the receiving countries. More importantly this strategy could buy popular support to more realistic migration policies in the individual EU countries. However, this could happen at the cost of reducing significantly the size of East-West migration flows. The issue is that migration is a two-sided and long-term investment: the migrant pays upfront the mobility costs and invests in future income streams, while absorbing the risk of not finding a job immediately, a risk which is rather high in Europe. Barring access to welfare in the initial years when the risk of unemployment is higher, is a strong deterrent to migration, including skilled and intra-EU migration, the type of mobility which is badly needed in Europe and the kind of migrants who can be better assimilated. Closing welfare may also just not be a feasible policy option. The US experience is revealing in this respect (Boeri, McCormick and Hanson, 2001): in 1996, the welfare system was partly decentralized to the states and limitations were introduced in the US to access to welfare benefits for legal immigrants. For instance, legal non-asylum immigrants who arrived in the country after August 1996 were barred from receiving food stamps or using Medicaid for 5 years. The proponents of this reform were hoping that a more decentralized system would make the states more cautious in providing expensive welfare benefits to immigrants. The reform failed on both accounts. Since 1996, the provision excluding immigrants from some welfare services has been challenged in the courts; and by 1997, the Congress started repealing the tougher provisions. Finally, the states felt the political pressure to maintain the benefits at the previous levels under the federal system; this is particularly evident in states like California, in which immigrants account for more than 15 percent of the electorate. This is bound to happen in Europe as well. There are numerous countries, among those some which already have absorbed a large number of migrants, which discuss to close welfare doors (like Germany, pushed to close welfare by the advisers to its Finance Minister). The new EU constitution however signed in Rome in October 2004 explicitly prohibits "discrimination on grounds of nationality" (article I-4) and establishes the principle that "everyone residing and moving legally within the EU is entitled to social security benefits and social advantages" (article II-34). Introducing national restrictions on access to welfare will likely open a Pandora's box of Court rulings. Many EU directives and decisions of the European Court of Justice have, after all, already introduced in the European material constitution non-discrimination clauses on the grounds of nationality and have explicitly recognized the entitlements to social security benefits and social services. Thus, a decentralized system that strongly discriminates against immigrants can face political resistance, is easily challengeable in courts and ultimately reverts to the previous system. 
A better policy for Europe could be the co-ordination of migration policies themselves towards third countries. This would avoid policy spillovers and hence overall involve a less restrictive approach. As to the nature of this co-ordination, we advocate a EU-wide immigration quota, regulating the entry via a point system allowing immigrants to freely choose the country of destination within the EU. A point system would encourage the type of migration which is most beneficial to Europe, notably skilled migration of young workers. Another advantage of having a point system in place is that it could greatly simplify migration regulations, e.g. making unnecessary ad-hoc policies for the highly-skilled migrants and integrating asylum policies in this broader framework (e.g., adopting humanitarian points). Finally a EU-wide point system could be easily adjusted to agreements with sending countries, potentially addressing the second type of coordination failure, namely the one between sending and receiving countries.

Overall, our analysis suggests that the bill paid by Europe for these co-ordination failures is high. The founding Members of the EU were aware of this co-ordination problem already in 1957 when they defined the free movement of labour as one of the four fundamental freedoms of the Common Market. The rules of the Community nowadays prevent that national governments increase migration barriers for EU-citizens or exclude them from welfare benefits. We documented that this increases aggregate income in the Community. As labour mobility in the Community is low and uncoordinated migration policies vis-à-vis third countries result in tighter migration restrictions, the EU should now make the second step, that is, it should co-ordinate the immigration policies vis-à-vis third country nationals. 


\section{References}

Alecke, B., P. Huber and G. Untiedt (2001), "What a difference a constant makes: how predictable are international migration flows?”, OECD (ed.): Migration Policies and EU Enlargement. The Case of Central and Eastern Europe, Paris, pp. 63-78.

Alvarez-Plata, P., H. Brücker and B. Siliverstovs (2003), Potential Migration from Central and Eastern Europe into the EU-15 - An Update, Report for the European Commission, DG Employment and Social Affairs, Brussels.

Arellano, M. and O. Bover (1995), Another look at the instrumental-variable estimation of error-components models, Review of Economic Studies, 58, pp. 277-97.

Arellano, M. and S. Bond, (1991), Some Tests of Specification for Panel Data: Monte Carlo Evidence and an Application to Employment Equations, Review of Economic Studies, 58, pp. 277-97.

Barro, R. and X. Sala-i-Martin (1991), Convergence across States and Regions, Brookings Papers on Economic Activity, No. 1, pp. 107-182.

Barro, R. and X. Sala-i-Martin (1995), Economic Growth, New York et al.: McGrawHill.

Bauer, T. (1997), "Do Immigrants Reduce Native Wages? Evidence from Germany”, Münchner Wirtschaftswissenschaftliche Beiträge 97, University of Munich.

Bauer, T. and K.F. Zimmermann (1999), Assessment of Possible Migration Pressure and Its Labour Market Impact Following EU Enlargement to Central and Eastern Europe, IZA Research Report No. 3, Bonn.

Bauer, T. and K.F. Zimmermann (1997), Looking South and East, Labour Markets Implications of Migration in Europe and LDCs, in: O. Memedovic, A. Kuyvenhoven, W.T.M. Molle (eds.), Globalisation and Labour Markets. Challenges, Adjustment and Policy Responses in the EU and the LDCs, Kluver, Dordrecht/Boston/London, 75-103.

Bean, C., R. Layard and S. Nickell (1986), The Rise in Unemployment: A MultiCountry Setting, Economica, 53, pp. S1-S22.

Benhabib, J. (1996) On the Political Economy of Immigration, European Economic Review.

Blonigen, B.A., R.B. Davies, K. Head (2003), „Estimating the knowledge-capital model of the multinational enterprise: comment", American Economic Review, Vol. 93, pp. 980-94.

Boeri, T. and H. Brücker et al. (2001): The Impact of Eastern Enlargement on Employment and Labour Markets in the EU Member States, Report for the European Commission, DG Employment and Social Affairs, Brussels.

Boeri, T., G.Hanson and B. McCormick, B. (eds.) (2002) Immigration Policy and the Welfare System, Oxford University Press, Oxford.

Bonin, H., B. Raffelhüschen und J. Walliser (2000): "Can immigration alleviate the demographic burden?”, FinanzArchiv, 57, 1-21.

Borjas, G.J. (2003), "The Labour Demand Curve is Downward-Sloping: Reexamining the Impact of Immigration on the Labour Market”, Quarterely Journal of Economics, November 2003, pp. 1335-1374.

Borjas, G.J. (1987), "Self-Selection and the Earnings of Immigrants", American Economic Review, 77(4), pp. 531-553.

Borjas, G.J. (2001), „Does Immigraton Grease the Wheels of the Labor Market?“, Brookings Papers on Economic Activity, 1, 69-133. 
Brücker, H. (2001), „Die Folgen der Freizügigkeit für die Ost-West-Migration. Schlussfolgerungen aus einer Zeitreihenanalyse der Migration nach Deutschland“, Konjunkturpolitik- Applied Economics Quarterly, Supplement 52, 17-54.

Brücker, H. (2002): "Can International Migration Solve the Problems of European Labour Markets”, UNECE Economic Survey of Europe, 2, 109-142.

Brücker, H., P.J.H. Schröder (2005), “International Migration With Heterogeneous Agents”, Mimeo, Aarhus School of Business.

Brücker, H. and B. Siliverstovs (2004), "On the Estimation and Forecasting of International Migration: How Relevant Is Heterogeneity Across Countries?", DIW-Discussion Paper No. 314.

Brücker, H. and M. Kohlhaas (2004), Migration, Qualification and Labor Markets, Mimeo, German Institute for Economic Research (DIW Berlin), 2004.

Burda, M.C. (1995), Migration and the Option Value of Waiting, Economic and Social Review, 27 (1), pp. 1-19.

Carr, D., J.R. Markusen, K.E. Maskus (2001), "Estimating the knowledge-capital model of the multinational enterprise”, American Economic Review, Vol. 91, pp. 693708.

Chiswick, B. (2000), “Are Immigrants Favourably Self-Selected? An Economic Analysis”, IZA Discussion Paper No. 131.

Collins, W.J, K.O'Rourke and J.G. Williamson, "Were trade and factor mobility substitutes in history?”, Faini, R., J. De Melo, K.F. Zimmermann (eds.), Migration. The Controversies and the evidence, Cambridge University Press, Cambridge, UK, pp. 227-259.

Danish Minister of Employment (2003), “Agreement among the Liberals, the Conservatives, the Social Democrats, the Socialist People's Party and the Christian Democrats Concerning Access to the Danish Labour Market after the Enlargement of the European Union on 1 May 2004,” Ministry of Employment, Copenhagen.

Decressin, J. and A. Fátas (1995), Regional Labour Market Dynamics in Europe, European Economic Review, 39(9), pp. 1627-57.

Djajic, S. and R. Milbourne (1988), A general equilibrium model of guestworker migration, Journal of International Economics, Vol. 25, pp. 335-351.

Dolmas, J. and Huffman, G. (2003), On the Political Economy of Immigration and Income Redistribution, mimeo.

Dustmann, C., M. Casanova, M. Fertig, I. Preston and C.M. Schmidt (2003), The impact of EU enlargement on migration flows, Home Office Online Report 25/03, http://www.homeoffice.gov.uk/rds/pdfs2/rdsolr2503.pdf.

Eurostat (2003): „Kaufkraftparitäten und abgeleitete Wirtschaftsindikatoren für EU, beitretende Länder, Beitrittskandidaten und EFTA“, Statistik kurz gefasst, No. 64/2003.

Faini, R. and A. Venturini (1995), Migration and Growth: The Experience of Southern Europe, CEPR Discussion Paper No. 964.

Faini, R., J. DeMelo and K.F. Zimmermann (1999), Migration. The Controversies and the Evidence, Cambridge: Cambridge University Press.

Fassmann, R. and C. Hintermann (1997), „Migrationspotential Ostmitteleuropa. Struktur und Motivation potentieller Migranten aus Polen, der Slowakei, Tschechien und Ungarn“, ISR-Scientific Report 15, Innsbruck.

Fertig, M. (2001), "The economic impact of EU enlargement: assessing the migration potential”, Empirical Economics, Vol. 26, pp. 707-720. 
Fertig, M. and C. M. Schmidt (2001), Aggregate-Level Migration Studies as a Tool for Forecasting Future Migration Streams, Discussionspaper No. 324, University of Heidelberg, Economics Department.

Flaig, G. (2001), „Die Abschätzung der Migrationspotentiale der osteuropäischen EUBeitrittsländer“, Konjunkturpolitik - Applied Economics Quarterly, Supplement 52, pp. 55-76.

Gavasto, A., A. Venturini and C. Villosio (1999), Do Immigrants Compete with Natives? Labour, 13(3), 603-622.

Geishecker, I. and H. Görg (2005), “The vertical investment controversy: re-estimating the knowledge-capital model for different types of FDI”, mimeo, University of Nottingham.

Hansen, J.D. (2003), "Immigration and income redistribution in welfare states", European Journal of Political Economy, 19, 735-746.

Hanson, G.H. and M.J. Slaughter (1999), The Rybczinski Theorem, Factor Price Equalization, and Immigration: Evidence from U.S. States, NBER Working Paper 7074, NBER, Cambridge, MA.

Harris, J.R. and M.P. Todaro (1970), "Migration, Unemployment and Development: A Two-Sector-Analysis”, American Economic Review, 60, pp.126-142.

Hassler, J., Krusell, P., Storesletten, K. and F. Zilibotti (2003), The Dynamics of Government: a positive analysis, mimeo.

Hatton, T.J. (1995), A Model of U.K. Emigration, 1870-1913, Review of Economics and Statistics, 77, pp. 407-415.

Hatton, T.j. (2004), Seeking Asylum in Europe, Economic Policy, April, pp. 5-62.

Heijdra, B., C. Keuschnigg, and W. Kohler (2002), Eastern Enlargement of the EU: Jobs, Investment and Welfare in the Present EU Member Countries, CESifo Working Paper No. 718 (7).

Helpman, E. (1984), “A Simple Theory of Trade with Multinational Corporations”, Journal of Political Economy, Vol. 92, pp. 451-71.

Helpman, E. and P.R. Krugman (1984), "Market Structure and Foreign Trade”, MIT Press, Cambridge, MA.

Hicks, J.R. (1932), The Theory of Wages, London: McMillan.

Hille, H. and T. Straubhaar (2001), "The Impact of EU-Enlargement on Migration Movements and Economic Integration: Results of Recent Studies”, in: OECD (ed.), Migration Policies and EU-Enlargement, Paris, pp. 79-100.

Home Office (2004a), “Consequences of EU Enlargement”, Memorandum, submitted to the House of Commons, The United Kingdom Parliament, London.

Home Office (2004b), "New Figures Show Accession Workers Working for the UK”, Home Office Press Releases, Reference: 351/2004, London: December 10.

Horstmann, I.J. and J.R. Markusen (1987), "Strategic Investments and the Development of Multinationals”, International Economic Review, Vol. 28, pp. 109-121.

Hunya, G. (2004), "Employment Effects of FDI in new EU members”, mimeo, WIIW, Vienna.

IOM (1998), Migration Potential in Central and Eastern Europe, Technical Cooperation Centre for Europe and Central Asia, International Organization for Migration (IOM), Geneva.

Judson, R.A. and A.K. Owen (1999): "Estimating dynamic panel data models: a guide for macroeconomists,” Economic Letters, 65, pp. 9-15.

Keuschnigg, C. and W. Kohler (2002), "Eastern Enlargement of the EU: How Much Is It Worth For Austria?”, Review of International Economics, 10, 324-342. 
Kiviet, J. (1995), „On Bias, Inconsistency and Efficiency of Various Estimators in Dynamic Panel Data Models”, Journal of Econometrics, 68, pp. 53-78.

Kohler, W. (2003), Eastern Enlargement of the EU: A Comprehensive Welfare Assessment, Department of Economics, Johannes Kepler University Linz, Working Paper No. 0316.

Krieger, T. (2003), Migration trends in an enlarged EU, European Foundation for the Improvement of Working and Living Conditions, Dublin.

Krugman, P. (1991), “Increasing Returns and Economic Geography”, Journal of Political Economy, 99, pp. 483-99.

Kvist, J. (2004), "Does EU enlargement start a race to the bottom? Strategic interaction among EU member states in social policy,” Journal of European Social Policy, 14(3), pp. 301-318.

Layard, R., O. Blanchard, R. Dornbusch and P. Krugman (1992): East-West Migration: The Alternatives. Boston: MIT Press.

Layard, R., S. Nickell and R. Jackman (1991), Unemployment. Oxford University Press, New York.

Lerner, A.P. (1952), “Factor Prices and International Trade”, Economica, Vol. 19, pp. 1-15.

Levine, P. (1999), “The welfare economics of migration control”, Population Economics, 12, pp. 23-43.

Löffelholz, H.-D. and G. Köpp (1998), Ökonomische Auswirkungen der Zuwanderung nach Deutschland, Schriftenreihe des Rheinisch-Westfälischen Instituts für Wirtschaftsforschung, New Series, No. 63, Berlin: Duncker und Humblot.

Ludema, R. and I. Wooton (1999), "Regional integration, trade and migration: are demand linkages relevant in Europe?”, in: Faini, R., J. DeMelo and K.F. Zimmermann (eds.), Migration. The Controversies and the Evidence, Cambridge: Cambridge University Press.

Maddison, A. (1995), Monitoring the World Economy 1820-1992, Paris: OECD.

Markusen, J.R. (2002), Multinational Firms and the Theory of International Trade, MIT-Press, Cambridge, MA.

Markusen, J.R. (1984), "Multinationals, Multi-Plant Economies and the Gains from Trade“, Journal of International Economics, Vol. 16, pp. 205-26.

Markusen, J.R. (1983), "Factor Movements and Commodity Trade as Complements", Journal of International Economics, Vol. 13, pp. 341-56.

Markusen, J.R. and A.J. Venables (1998), „Multinational Firms and the New Trade Theory“, Journal of International Economics, Vol. 46, pp. 183-203.

Mayda, A. and Rodrik, D. (2001), "Why are Some People (and Countries) More Protectionist than Others?”, NBER Working Paper No. 8461.

Metzler, A. and S. Richard (1981) A Rational Theory of the Size of Government, Journal of Political Economy.

Mundell, R. (1957), "International Trade and Factor Mobility”, American Economic Review, Vol. 47, pp. 321-35.

Nickell, S. (1981), „Biases in dynamic models with fixed effects“, Econometrica, 49, pp. 1417-1426.

OECD (2001) International Migration of the Highly Skilled, Paris: OECD.

O’Rourke, K. (2003), Heckscher-Ohlin Theory and Individual Attitudes Towards Globalisation, NBER Working Paper No. 9872. 
Puhanyi, P.A. (2001), "Is Labour Mobility an Adjustment Mechanism for Euroland? Empirical Evidence for Western Germany, France, and Italy,” German Economic Review, 2, pp.127-40.

Razin, A., Sadka, E. and P. Swagel (2002), “Tax Burden and Migration: A political economy theory and evidence", Journal of Public Economics.

Rodrik, D. (2002), “Final Remarks”, in: Faini, R., J. DeMelo, K.F. Zimmermann (eds.), Migration. The Controversies and the Evidence, Cambridge: Cambridge University Press, pp. 314-317.

Roodenburg, H., R. Euwals and H. ter Rele (2003), Immigration and the Dutch economy, Den Hague: CPB \& Koninklijke De Swart.

Roy, A.D. (1951), "Some Thoughts on the Distribution of Earnings", Oxford Economic Papers, 3, pp. 314-317.

Salop, S. (1979), “A Model of the Natural Rate of Unemployment”, American Economic Review, 74, pp. 117-125.

Samuelson, P.A. (1949), "International Factor-Prize Equalization Once Again”, Economic Journal, Vol. 59, pp. 181-97.

Scheve, K. and Slaughter (2001), "Labor-Market Competition and Individual Preferences Over Immigration Policy”, Review of Economics and Statistics.

Shapiro, C., and J. Stiglitz (1984), "Equilibrium Unemployment as a Worker Discipline Device”, American Economic Review, 74, pp. 433-444.

Sinn, H.-W., (2000), "EU Enlargement and the Future of the Welfare State", Distinguished Address, Atlantic Economic Society, March.

Sinn, H.-W., G. Flaig, M. Werding, S. Münz, N. Düll and H. Hoffmann (2001), EUErweiterung und Arbeitskräftemigration. Wege zu einer schrittweisen Annäherung der Arbeitsmärkte, Munich: Ifo-Institut für Wirtschaftsforschung.

Sjaastad, L.A. (1962), “The costs and returns of human migration”, Journal of Political Economy, Vol. 70(5), pp. 80-93.

Trabold, H. and P. Trübswetter (2001), Schätzung der Beschäftigungs- und Lohneffekte der Zuwanderung, in: Brücker, H., H. Trabold, P. Trübswetter, C. Weise, Migration: Potential und Effekte für den deutschen Arbeitsmarkt, Final Report for the Hans-Böckler-Foundation, German Institute for Economic Research (DIW), Berlin.

Trefler, D. (1997), Immigrants and Natives in General Equilibrium Trade Models. NBER Working Paper No. 6209, Cambridge, MA: NBER.

UN/ECE (2005), Economic Survey of Europe, No. 1/2005, United Nations, Geneva.

Venables, A. (1999), "Trade Liberalisation and Factor Mobility: An Overview", in: Faini, R., J. DeMelo and K.F. Zimmermann (eds.), Migration. The Controversies and the Evidence, Cambridge: Cambridge University Press, pp. 23-47.

Winter-Ebmer, R. and J. Zweimüller (1996), "Immigration and the Earnings of Young Native Workers”, Oxford Economic Papers, 48, pp. 473-491. 


\section{Appendix A Estimation of the migration potential}

The model on which the estimate of the migration potential in Section 1.3 is based explains migration stocks by the income differential between the receiving and the sending country, the income in the home country, and the employment rates in the receiving the sending country. More specifically, the long-run relationship between migration stocks and the explanatory variables is given by

$$
m s t_{i t}=a_{1} \ln \left(w_{f t} / w_{i t}\right)+a_{2} \ln \left(w_{i t}\right)+a_{3} \ln \left(e_{f t}\right)+a_{4} \ln \left(e_{i t}\right)+\mu_{i}+\varepsilon_{i t},
$$

where $m s t_{i t}$ denotes the migrant stock as a percentage of the population in country $i, w_{f t}$ and $w_{i t}$ the wage rates in the receiving and the source county, respectively, $e_{f}$ and $e_{i}$ the employment rates in the receiving and source county, respectively, $\mu_{i}$ a country-specific fixed effect, and $\varepsilon_{i t}$ the error term. Finally, $i=1, \ldots, N$ and $t=1, \ldots, T$ are the (source) country and time indices, and $f$ denotes the host country.

This parsimonious specification of the migration function has a long tradition in the literature. The choice of economic variables is primarily based on the classical contributions of Hicks(1932), Sjaastad (1962) and Harris and Todaro (1970). Following the expected income hypothesis of Harris and Todaro (1970), it is assumed that individuals form expectations on income levels, which are conditioned by the employment opportunities in the respective locations. Home income has been added as an additional variable to the income differential, since liquidity constraints might affect the propensity to migrate (Faini and Venturini, 1995). Thus, it is expected that the income differential, home income and the employment rate in the host country have a positive sign, while the employment rate in the sending country has a negative sign.

One feature sets the model employed here apart from the traditional specification of macro migration functions. While most models in the literature assume that a long-run equilibrium relationship between migration flows and the explanatory variables exists, it is stated here that an equilibrium between migration stocks and the explanatory variables emerges in the long-run. While the flow-model is based on the assumption that all individuals are homogeneous with regard to their preferences and human characteristics, the stock-model assumes that individuals are heterogeneous. As a consequence, for a given difference in expected income levels, the equilibrium migration stock is achieved eventually when the benefits of migration equals its costs for the marginal migrant. Note that the stock model does not rely on the assumption that all migration is permanent. In contrast, under the assumption of heterogeneity, the duration of migration varies across individuals. In equilibrium, the emigration from younger cohorts equals the return migration from older cohorts, as long as the rate of natural population growth is similar in the home population and the migrant population. ${ }^{18}$

The hypothesis, whether migration stocks or flows and the explanatory variables are characterised by an equilibrium relationship, or, in more technical terms, are cointegrated, can be tested statistically. For our data set ${ }^{19}$ we can prove that explanatory variables (GDP per capita, employment rates) and the migration stocks are instationary and follow the same stochastic process, ${ }^{20}$ while the migration rates are stationary. Thus,

\footnotetext{
${ }^{18}$ See Brücker and Schröder (2005) for a formal derivation of the stock model.

${ }^{19}$ The descriptive statistics is available from the authors upon request.

${ }^{20}$ In technical terms, they are all integrated of order one, i.e. I(1) variables.
} 
the migration rate and the left-hand variables cannot be cointegrated. Moreover, we cannot reject the hypothesis that the migration stocks and the explanatory variables are cointegrated for our data set, i.e. that a long-run equilibrium relationship exists between this variables. ${ }^{21}$

This allows us to estimate a panel cointegration model. The final estimation equation is specified in form of an error correction mechanism (ECM), which enables us to estimate both the long-term cointegrating vector and the short-run dynamics. Note that the ECM is a very flexible functional form and imposes few restrictions on the adjustment process. Specifically, the estimation equation has the form

$$
\begin{aligned}
\Delta m s t_{i t}= & b_{1} m s t_{i, t-1}+b_{2} \ln \left(w_{f} / w_{i}\right)_{t-1}+b_{3} \ln \left(w_{i}\right)_{t-1}+b_{4} \ln \left(e_{f}\right)_{t-1}+b_{5} \ln \left(e_{i}\right)_{t-1}, \\
& +b_{6} \Delta \ln \left(w_{f} / w_{i}\right)_{t}+b_{7} \Delta \ln \left(w_{i t}\right)+b_{8} \Delta \ln \left(e_{f t}\right)+b_{9} \ln \left(e_{i t}\right)+b_{10} \Delta m s t_{i, t-1} \\
& +\boldsymbol{\eta}^{\prime} \mathbf{z}_{i t}+\mu_{i}+\varepsilon_{i t}
\end{aligned}
$$

where $\mathbf{z}_{\text {it }}$ is a vector of institutional variables, $\eta$ is the corresponding vector of coefficients, and $\Delta$ is the first-difference operator. Three dummy variables are considered here which should capture different institutional conditions for migration: guestworker agreements between the source country and Germany, free movement between the source country and Germany, and dictatorship in the source country. The first two variables should capture reduced legal and administrative barriers for migration, the last variable a political 'push' factor in the source country.

Table A1 reports the estimation results. In all three regressions we find a positive and significant sign for the income differential, the income in the sending country and the employment rate in the receiving country, and a negative and significant sign for the employment rate in the sending country. Thus, the results for the economic variables confirm our expectations. With regard to the institutional variables, guestworker recruitment and dictatorship in the sending country have a positive and significant impact on migration. The dummy variable for the free movement in the EU appears only significant in the last regression.

The three estimation models presented in Table A1 impose different restrictions on the error term. The first estimator is a standard fixed effects estimator, which assumes that the errors are homoscedastic, and that they are not correlated across groups. The second estimator allows for heteroscedasticity in the error terms, and the third estimator for both, heteroscedasticity and correlation across groups (spherical disturbances). The test statistics show that (i) the model which allows for heteroscedastic errors is preferable relative to the model which assume homoscedastic error terms, and that (ii) the model which allows for both heteroscedastic and correlated error terms is preferable relative the model which allows only for heteroscedastic errors. Thus, we base our projection of the migration potential on the last specification of the estimation model.

\footnotetext{
${ }^{21}$ The results of the panel unit-root tests and the panel cointegration tests are available from the authors upon request.
} 
Table A1 Estimation Results

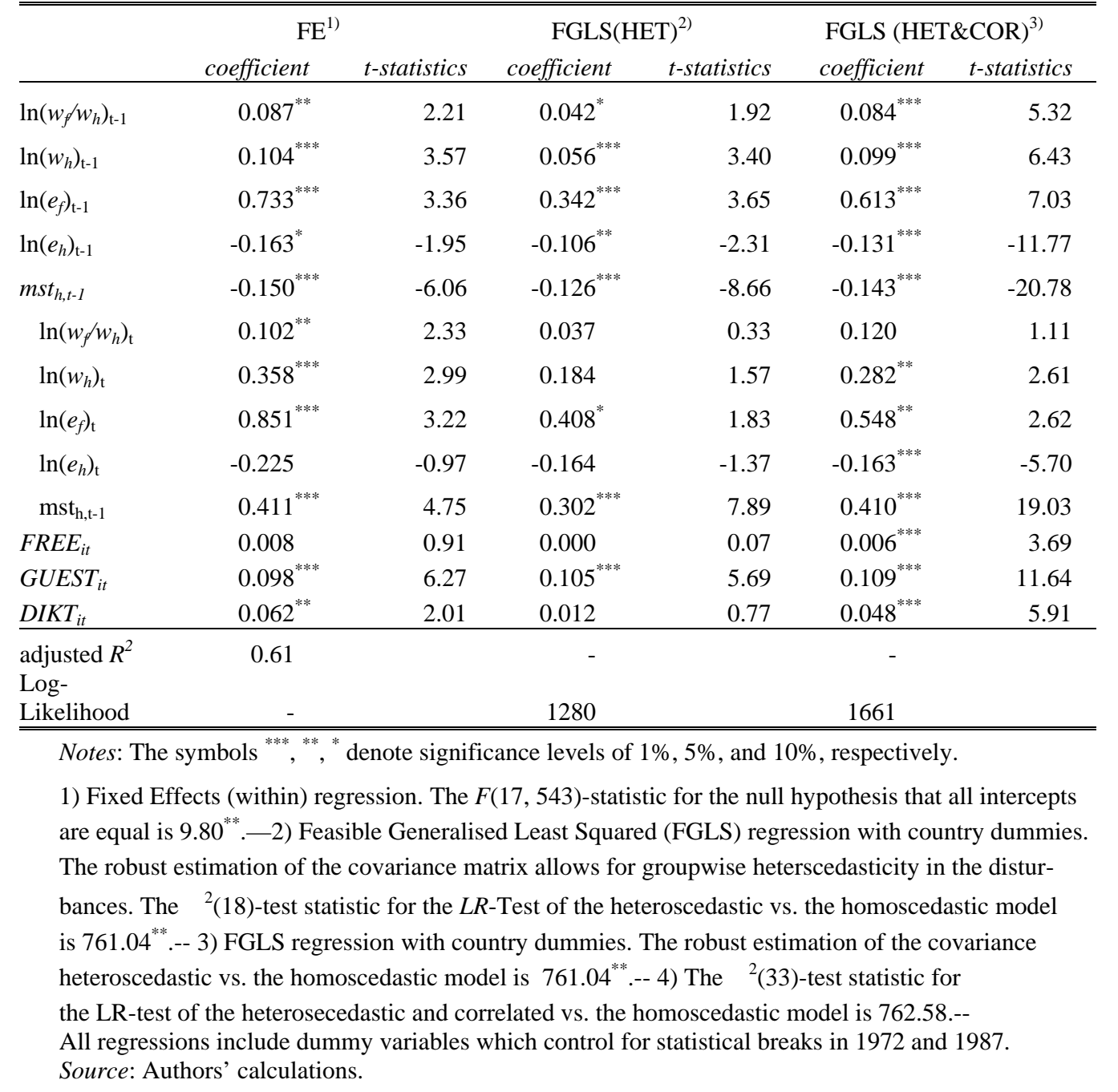

Two other technical aspects are worthwhile to mention: First, the regression diagnostics clearly rejects the assumption that the intercept terms are uniform across countries. This is particularly important since some estimates of the migration potential employ pooled ordinary least squares (OLS) models, which rely on the assumption that the intercept term is equal (Sinn et al., 2001; Flaig, 2001). This hypothesis is not only rejected by specification tests, a comparison of the pooled OLS and fixed effects estimators also show that the forecasting performance of the pooled OLS models is weak (Brücker and Siliverstovs, 2004).

Second, it is well-known that dynamic fixed effects or pooled OLS model might be subject to an estimation bias if the lagged dependent variable is correlated with the error term (Nickell, 1981). This bias disappears with the time dimension of the panel, but can still affect results in our data set with 32 observations over time (Judson and Owen, 1999). There exist several estimation procedures which address this bias, inter alia the Generalised Methods of Moments (GMM) estimators by Arellano and Bond (1991) and Arellano and Bover (1995). However, since the group dimension of our panel is relatively small, the efficiency of these estimators can be weak in our data set. Indeed, it can be shown that the forecasting performance of these GMM-estimators is poor 
relative to the fixed effects estimators presented in Table A1 (Brücker and Siliverstovs, 2004).

The projection of the migration potential for countries out-of-sample involves the problem that the intercept term differs between individual countries in the fixed effects regression. These differences reflect the impact of time-invariant variables such as geography, language, culture, etc. on migration. We follow here the procedure by Fertig (2001) and Brücker and Boeri (2001) and explain the fixed effects in a second regression by time-invariant variables. More specifically, we regress the fixed effects obtained in the first regression against geographical distance, distance squared, a dummy variable for geographical proximity (ADJACENT), a dummy variable for geographical location in the East of Europe (EAST), and a dummy for common language. These variables explain almost 90 per cent of the variance in the fixed effects (Table A2).

\section{Table A2 Explanation of country-specific fixed effects}

\begin{tabular}{|c|c|c|c|c|c|c|}
\hline \multirow{3}{*}{ observations } & \multirow{2}{*}{\multicolumn{2}{|c|}{$\begin{array}{l}\mathrm{FE} \\
18\end{array}$}} & \multirow{2}{*}{\multicolumn{2}{|c|}{$\begin{array}{c}\mathrm{FE}(\mathrm{HET}) \\
18\end{array}$}} & \multirow{2}{*}{\multicolumn{2}{|c|}{$\begin{array}{c}\text { FE(HET\&COR) } \\
18\end{array}$}} \\
\hline & & & & & & \\
\hline & coefficient & $t$-statistics & coefficient & $t$-statistics & coefficient & t-statistics \\
\hline dist $\times 1,000$ & $-0.464^{* *}$ & -2.59 & $-0.430^{* * *}$ & -2.88 & $-0.450^{* * *}$ & -2.64 \\
\hline $\operatorname{dist}^{2} \times 1,000,000$ & $0.403^{* * *}$ & 3.35 & $0.369^{* * *}$ & 3.67 & $0.388^{* * *}$ & 3.39 \\
\hline ADJACENT & $0.204^{* * *}$ & 4.76 & $0.176^{* * *}$ & 4.96 & $0.195^{* * *}$ & 4.81 \\
\hline EAST & 0.041 & 0.85 & 0.032 & 0.81 & 0.039 & 0.85 \\
\hline LANGUAGE & 0.073 & 1.62 & 0.056 & 1.49 & 0.067 & 1.57 \\
\hline CONSTANT & $-0.839^{* * *}$ & -13.75 & $-0.394^{* * *}$ & -7.75 & $-0.795^{* * *}$ & -13.70 \\
\hline adjusted $R^{2}$ & 0.87 & & 0.87 & & 0.87 & \\
\hline$F$-statistic & 22.88 & & 24.67 & & 23.08 & \\
\hline
\end{tabular}

The regression results for the intercept term in Table A2 and for the slope parameters in Table A1 are then used for the simulation of the migration potential from the CEEC-10 to Germany, which are presented in Table 1.4 in the main text. The assumptions with regard to the explanatory variable are described there as well. 


\section{Appendix B Description of the simulation model}

The simulations in Section 3 are based on a highly stylised model of two economies, which produce one good and are - beyond migration and capital movements - closed. In this annex we describe the basic features of the model (see also Brücker, 2002). Many aspects of the model described here draw on Levine (1999), but in contrast to the Levine model we conceive that the labour market is split in an unskilled and a highskilled segment and that the elasticity of wages with respect to the unemployment rate differs between the segments (see Bauer/Zimmermann 1997 for a similar assumption). Moreover, we consider a number of other features like unemployment benefits, regional wage and employment differences and treat the volume of migration as endogenous in a later stage of the analysis. The model relies of course on a number of arbitrary assumptions, but it nevertheless allows to analyse some of the fundamental mechanisms by which migration may affect income, employment and welfare of the affected parties in the host and source countries.

\section{Outline of the basic model}

The output of the economies in the host and the source country for migration is produced with unskilled labour, skilled labour and physical capital. Production technologies have constant returns to scale and are approximated by a Cobb-Douglas function, such that

$$
Y_{i}=\bar{A}_{i} L_{i}^{\alpha_{i}} H_{i}^{\beta_{i}} K_{i}^{1-\alpha_{i}-\beta_{i}}, \quad i=f, h,
$$

where $Y_{i}$ denotes output, $\bar{A}_{i}$ a productivity parameter, which reflects the level of technology and institutions, $L_{i}$ unskilled labour, $H_{i}$ skilled labour, and $K_{i}$ physical capital. $\alpha_{i}, \beta_{i}$, and $1-\alpha_{i}-\beta_{i}$ are the shares of unskilled labour, skilled labour and capital, respectively, in total income, and $i \in\{f, h\}$ is an index for the country of destination, $f$, and the country of origin, $h$, respectively. Let $\bar{N}_{i}$ be the initial, premigration, endowment of country $i$ with unskilled labour, and let $\bar{S}_{i}$ be its initial endowment with skilled labour. Then the post-migration allocation of unskilled labour in the country of destination and the source country is given by

$$
N_{f}=\bar{N}_{f}+\gamma M, \quad N_{h}=\bar{N}_{h}-\gamma M,
$$

where $M$ denotes the number of migrants, and $\gamma$ the proportion of unskilled labour in the migrant population. Analogously, the post-migration allocation of skilled labour can be written as

$$
S_{f}=\bar{S}_{f}+(1-\gamma) M, \quad S_{h}=\bar{S}_{h}-(1-\gamma) M,
$$

where $1-\gamma$ denotes the proportion of skilled workers in the migrant population. In all simulations we assume that the total labour force, i.e. the number of skilled and unskilled workers, is equal in the host and the home country in the pre-migration state. The model has a comparative static character in the sense that capital accumulation is not considered and that the productivity parameter is assumed to be fixed.

Wages and the demand for labour are determined sequentially. In the first stage, wages are fixed by a bilateral bargaining monopoly between trade unions and employer 
federations. ${ }^{22}$ In the second stage, profit-maximising firms hire labour until the marginal product of labour equals the wage rate; the participants in the wage negotiations are aware of this. Given this wage-setting mechanism, wages respond - albeit imperfectly to the unemployment rate in the economy as well as to other factors such as capital endowments which affect labour productivity. This allows us to express the wage rate for unskilled and skilled labour, respectively, as functions of the unemployment rate and capital endowments in the economy, i.e. as

$$
w_{L, i}=f_{i}\left(u_{L, i}, K_{i}\right), \quad f_{u, i}<0, f_{K, i}>0
$$

and

$$
w_{H, i}=g_{i}\left(u_{H, i}, K_{i}\right), \quad g_{u, i}<0, g_{K, i}>0,
$$

where $f_{u, i}$ and $g_{u, i}$ denote the partial derivative of the wage rates with respect to the unemployment rate, and $f_{K, i}$ and $g_{K, i}$ the partial derivatives of the wage rates with respect to the capital stock in economy $i$. The unemployment rates for unskilled and skilled labour are defined as $u_{L, i}=1-L_{i} /\left(N_{i}\right)$ and $u_{H, i}=1-H_{i} /\left(S_{i}\right)$, respectively. Thus, we allow the elasticity of wages with respect to the unemployment rate to differ for unskilled and skilled labour.

Assume for the moment that the endowment with physical capital is fixed, i.e. that $K_{i}=\bar{K}_{i}$. The impact of migration on employment is then determined by the marginal product of skilled and unskilled labour and the flexibility of wages in the respective labour markets, i.e. by

$$
\alpha_{i} \bar{A}_{i} L_{i}^{-\left(1-\alpha_{i}\right)} H_{i}^{\beta_{i}} \bar{K}_{i}^{1-\alpha_{i}-\beta_{i}}=f_{i}\left(1-\frac{L_{i}}{N_{i}}\right),
$$

and

$$
\beta_{i} \bar{A}_{i} L_{i}^{\alpha_{i}} H_{i}^{-\left(1-\beta_{i}\right)} \bar{K}_{i}^{1-\alpha_{i}-\beta_{i}}=g_{i}\left(1-\frac{H_{i}}{S_{i}}\right),
$$

where we used the definitions for the unemployment rate on the right-hand side.

Equations (B6) and (B7) are a system of four equations which determine, together with the production function in equation (B1) and the definitions in equations (B2)-(B5), the values for $L_{f}, L_{h}, H_{f}$ and $H_{h}$. Write the semi-elasticity of the wage of unskilled labour with respect to unemployment as $\eta_{i}=-f_{u, i}\left(u_{L, i}\right) / w_{L, i}$, and, analogously, the semielasticity of the wage of skilled labour with respect to unemployment as $\mu_{i}=-g_{u, i}\left(u_{H, i}\right) / w_{H, i} \cdot{ }^{23}$ Differentiating the system in equations (B6) and (B7) implicitly with respect to $M$ and substituting from (B1)-(B5) yields then -- after a good deal of

22 The argument elaborated here is consistent with different modes of wage setting, e.g. models with a monopoly union or a bilateral bargaining monopoly (e.g. Layard et al. 1992), efficiency wage theories (e.g. Salop 1979) or shirking-models (Shapiro and Stiglitz 1984). The analysis considers however only the long-run response of wages to a change in labour supply, i.e. the impact of short-run fluctuations in (un-) employment rates is ignored (Levine 1999).

${ }^{23}$. Note that this implies that the elasticities of the wage rate for unskilled and skilled labour with respect to the unemployment rate are $\eta_{I} u_{L, i}$ and $\mu_{. i} u_{S, i}$, respectively. 
algebra -- the marginal response of employment of unskilled and skilled labour to migration in both economies:

$$
\begin{aligned}
& \frac{d L_{f}}{d M}=\left(1-u_{L, f}\right) \frac{\left.\gamma \eta_{f}\left(1-u_{L, f}\right)\left(1-\beta_{f}\right)+\mu_{f}\left(1-u_{H, f}\right)\right]+(1-\gamma)\left(1-u_{H, f}\right) \beta_{f} \mu_{f} N_{f} / S_{f}}{\left[\left(1-\alpha_{f}\right)+\eta_{f}\left(1-u_{L, f}\right)\right]\left[\left(1-\beta_{f}\right)+\mu_{f}\left(1-u_{H, f}\right)\right]-\alpha_{f} \beta_{f}}, \\
& \frac{d L_{h}}{d M}=-\left(1-u_{L, h}\right) \frac{\gamma \eta_{h}\left(1-u_{L, h}\right)\left[\left(1-\beta_{h}\right)+\mu_{h}\left(1-u_{H, h}\right)\right]+(1-\gamma)\left(1-u_{H, h}\right) \beta_{h} \mu_{h} N_{h} / S_{h}}{\left[\left(1-\alpha_{h}\right)+\eta_{h}\left(1-u_{L, h}\right)\right]\left[\left(1-\beta_{h}\right)+\mu_{h}\left(1-u_{H, h}\right)\right]-\alpha_{h} \beta_{h}}, \\
& \frac{d H_{f}}{d M}=\left(1-u_{H, f}\right) \frac{(1-\gamma)\left(1-u_{H, f}\right) \mu_{f}\left[\left(1-\alpha_{f}\right)+\eta_{f}\left(1-u_{L, f}\right)\right]+\gamma\left(1-u_{L, f}\right) \alpha_{f} \eta_{f} S_{f} / N_{f}}{\left[\left(1-\alpha_{f}\right)+\eta_{f}\left(1-u_{L, f}\right)\right]\left[\left(1-\beta_{f}\right)+\mu_{f}\left(1-u_{H, f}\right)\right]-\alpha_{f} \beta_{f}}, \\
& \frac{d H_{h}}{d M}=-\left(1-u_{H, h}\right) \frac{(1-\gamma)\left(1-u_{H, h}\right) \mu_{h}\left[\left(1-\alpha_{h}\right)+\eta_{h}\left(1-u_{L, h}\right)\right]+\gamma\left(1-u_{L, h}\right) \alpha_{h} \eta_{h} S_{h} / N_{h}}{\left[\left(1-\alpha_{h}\right)+\eta_{h}\left(1-u_{L, h}\right)\right]\left[\left(1-\beta_{h}\right)+\mu_{h}\left(1-u_{H, h}\right)\right]-\alpha_{h} \beta_{h}} .
\end{aligned}
$$

Thus, the higher the flexibility of labour markets, i.e. the higher the semi-elasticity between the wage and the unemployment rate, the higher is the marginal response of employment with respect to migration.

Consider two extreme cases: in the first case, the labour markets are completely flexible, i.e. $\eta_{i} \rightarrow \infty, \mu_{i} \rightarrow \infty$ and $L_{i} \rightarrow N_{i}, H_{i} \rightarrow S_{i}$. In this case, equations (B8) and (B10) converge to $\gamma$ and (1- $\gamma$ ), respectively, and equations (B9) and (B11) to - $\gamma$ and -(1$\gamma)$, respectively. The labour force in the host country increases then exactly by the number of immigrant workers, and the labour force in the home country is exactly reduced by the number of migrant workers. This case corresponds to the textbook example of the impact of migration in an economy with clearing labour markets and an inelastic supply of native labour (e.g. Wong 1995, pp. 628-632). In the other extreme case, wages for unskilled labour are perfectly inflexible, i.e. $\eta_{i} \rightarrow 0$, while wages for skilled labour are perfectly flexible, i.e. $\mu_{i} \rightarrow 0$. In this case, immigration of unskilled workers does not change employment of unskilled workers, such that it simply increases unemployment of unskilled workers in host countries. However, the immigration of skilled workers increases employment of unskilled workers in host countries, since skilled and unskilled workers are complements under the assumptions of our model. Thus, the impact of migration on (un-) employment and income depends essentially on the composition of the migrant population with respect to their skill levels. The cases of flexible labour markets and wage rigidities are calibrated in Table 3.1 of Section 3.

\section{The impact of capital mobility}

Capital mobility can be treated analogously to labour mobility. Changes in the endowment with physical capital affects the marginal productivity of unskilled and skilled labour and, hence, labour demand. Assume again that wages and the demand for labour are determined sequentially. Since capital is not fixed, wages respond now to both, changes in the unemployment rate and changes in the endowment with capital. Write the semi-elasticity of the wage of unskilled labour with respect to physical capital as $\omega_{i}=f_{K, i} / w_{L, i}$, and, analogously, the semi-elasticity of the wage of skilled labour with respect to unemployment as $\varpi_{i}=g_{K, i} / w_{H, i}$. We can then differentiate the system 
in equations (B6)-(B7) implicitly with respect to physical capital, which gives after substitution from (B1)-(B5) for the marginal response of employment of unskilled and skilled labour to a change in the physical capital endowments

$$
\frac{d L_{i}}{d K_{i}}=\left(1-u_{L, i}\right) N_{i} \frac{\left(1-\alpha_{i}-\beta_{i}\right)\left[1+\left(1-u_{H, i}\right) \mu_{i}\right] / K_{i}-\left[\beta_{i} \varpi_{i}+\left(1-\beta_{i}\right) \omega_{i}\right]-\left(1-u_{H, i}\right) \mu_{i} \omega_{i}}{\left[\left(1-\alpha_{i}\right)+\left(1-u_{L, i}\right) \eta_{i}\right]\left[\left(1-\beta_{i}\right)+\left(1-u_{H, i}\right)\right]-\alpha_{i} \beta_{i}},
$$

and

$$
\frac{d H_{i}}{d K_{i}}=\left(1-u_{H, i}\right) S_{i} \frac{\left(1-\alpha_{i}-\beta_{i}\right)\left[1+\left(1-u_{L, i}\right) \eta_{i}\right] / K_{i}-\left[\alpha_{i} \omega_{i}+\left(1-\alpha_{i}\right) \varpi_{i}\right]-\left(1-u_{L, i}\right) \eta_{i} \varpi_{i}}{\left[\left(1-\alpha_{i}\right)+\left(1-u_{L, i}\right) \eta_{i}\right]\left[\left(1-\beta_{i}\right)+\left(1-u_{H, i}\right)\right]-\alpha_{i} \beta_{i}} .
$$

\section{The allocation of jobs among natives and migrants}

For an analysis of the impact of migration on income of natives and migrants, it is necessary to make additional assumptions on the employment opportunities of natives and migrants. Following the traditional approach of Harris and Todaro (1970), we assume that in each period all jobs are randomly allocated among the total labour force, i.e. among natives and migrants. However, we modify the selection process in allowing for the possibility that employment opportunities of migrants are below that of natives, i.e.

$$
p_{M L, f}=\lambda\left(1-u_{L, f}\right), \quad p_{N L, f}=\left(1+(1-\lambda) \gamma M / N_{f}\right)\left(1-u_{L, f}\right),
$$

and

$$
p_{H L, f}=\lambda\left(1-u_{L, f}\right), \quad p_{N H, f}=\left(1+(1-\lambda)(1-\gamma) M / N_{f}\right)\left(1-u_{H, f}\right) \text {, }
$$

where $p_{M j}$ and $p_{N j}$ denote the employment probability for migrants and natives in the host country, respectively $(j=L, H)$, and the factor $\lambda(0<\lambda \leq 1)$ accounts for the possibility that the employment opportunities of migrants are below that of natives. Note that this implies that some of the employment risks of natives are shifted to migrants. For natives in the home country we assume that the employment probabilities are simply given by

$$
p_{L, h}=1-u_{L, h}, \quad p_{H, h}=1-u_{H, h} .
$$

\section{The role of unemployment benefits}

Migration does not only affect income by wages and employment, but also by welfare benefits. In order to consider the impact on welfare benefits, we assume that unemployment benefits are a fixed proportion of post-tax wages, i.e. $b_{i}\left(1-t_{i}\right) w_{i j}$, where $t_{i}$ denotes an uniform income tax-rate, $i=f, h$, the respective country, and $j=L, H$, skilled and unskilled labour, respectively. Physical capital is not taxed. If we assume that the budget is balanced and if we ignore all other public expenditures, then taxes must equal unemployment costs, which gives for the tax rate

$$
t_{i}=b_{i} \frac{w_{L i} u_{L i} N_{i}+w_{H i} u_{H i} S_{i}}{\left(1-\left(1-b_{i}\right) u_{L i}\right) w_{L i} N_{i}+\left(1-\left(1-b_{i}\right) u_{H i}\right) w_{H i} S_{i}},
$$

where $N_{i}$ and $S_{i}$ are the post-migration endowments with unskilled and skilled labour as determined by equations B2 and B3. The impact of a different size of unemployment benefits and, hence, different tax rates, on the income of natives and migrants are calibrated in Table 3.3 in Section 3. 


\section{Endogenous migration}

So far we have assumed that the migration rate is given. For an analysis of the impact of migration policies on welfare it is however necessary to consider also the determinants of the migration rate. We limit our analysis here to the simple case of permanent migration (see again Levine 1999 for a similar approach).

Assume that migrants do not own physical capital. The net present value of expected income in the foreign country for an infinitively living household is then given by

$$
V_{f j t}=\sum_{\tau=0}^{\infty} \delta^{\tau}\left[p_{f j t+\tau}+b_{f}\left(1-p_{f j t}\right)\right] \tilde{w}_{f j t}, j=L, H,
$$

and in the home country by

$$
V_{h j t}=\sum_{\tau=0}^{\infty} \delta^{\tau}\left[p_{h j t+\tau}+b_{h}\left(1-p_{h j t}\right)\right] \tilde{w}_{h j t}, j=L, H,
$$

where $\delta<1$ denote the discount factor, and $\widetilde{w}_{i j t}=\left(1-t_{i}\right) w_{i j t}$ the post-tax wage. The employment probabilities are given by equations (B12) and (B13).

For convenience we assume that manual workers expect that the following generations will remain manual workers, too, while for non-manual workers the converse holds. A risk-neutral individual will migrate if the difference in the net present value from living in a foreign country and at home exceeds the net present value of all pecuniary and nonpecuniary costs of migration, i.e. if

$$
V_{f j, t}-V_{h j, t} \geq \sum_{\tau=0}^{\infty} \delta^{\tau} C_{j, t+\tau}
$$

If we write the migration costs on the left hand side of (B18) as a fraction of the net present value of living at home, i.e. as $c V_{h j t}$, then a factor $1 /(1-\delta)$ cancels out and we obtain

$$
\frac{p_{j f}+b_{f}\left(1-p_{f}\right)}{p_{h}+b_{h}\left(1-p_{h}\right)} \frac{\tilde{w}_{j f}}{\tilde{w}_{j h}} \geq 1+c_{j},
$$

i.e. the ratio of expected real income in the foreign and the home country has to exceed the cost factor $1+c_{j}$. Note that there are no transitional dynamics in the system and all variables jump immediately to its steady state values such that we can drop the time subscript (Levine 1999).

Following Faini and Venturini (1995), Ludema and Wooton (1999) and Brücker and Schröder (2005), we assume that individuals differ with respect to their preferences and their costs to migrate. In the steady state, the net present value of expected income equals just the net costs of migration for the marginal migrant. Thus, we assume that a macroeconomic function exists, which determines the share of migrants in the home population as a function of the expected difference in per capita income in the steady state. Depending on assumptions about the distribution of the costs to migrate and preferences across the population, we can conceive different functional forms. For our 
simulations, we assume that the share of migrants in the labour force of the home population is a semi-logarithmic function of the ratio of expected income. This functional form is conceived in several macro studies on the determinants of migration (e.g. Hatton, 1995; Boeri and Brücker, 2001). Thus, the steady state share of migrants in the force of unskilled workers of the source country is given by the probability that the ratio of expected income in the host and the home country equals the costs for migration for the $k^{\text {th }}$ individual, i.e. by

$$
\frac{\gamma M}{\bar{N}_{h}}=\operatorname{Pr}\left(\frac{V_{L, f}}{V_{L, h}} \geq 1+c_{L, k}\right)=\theta \ln \left(\frac{V_{L, f}}{V_{L, h}}\right),
$$

and the steady state share of migrants in the force of skilled workers analogously by

$$
\frac{(1-\gamma) M}{\bar{S}_{h}}=\operatorname{Pr}\left(\frac{V_{H, f}}{V_{H, h}} \geq 1+C_{H, n}\right)=\sigma \ln \left(\frac{V_{H, f}}{V_{H, h}}\right),
$$

i.e. we allow that the propensity to migrate differs for skilled and unskilled workers.

Based on these assumptions, we calibrated in Table 2.4 in Section 2 the impact of the income differential and different rates of unemployment benefits on the overall migration potential and the shares of unskilled and skilled workers in the migrant population.

\section{Are migration and capital mobility substitutes or complements?}

Under the assumptions of this simple model, East-West migration increases aggregate GDP in the receiving countries and reduces it in the sending countries. The impact on the GDP per capita in the receiving and the sending countries is ambiguous, it depends on labour market conditions and human capital endowments of the migrant population. Whether the convergence of GDP levels tends to increase or to decrease international capital flows, is an open question. The theoretical and empirical literature on foreign direct investment distinguishes between 'vertical' and 'horizontal' forms of international investment activities. The basis for our analysis of the impact of migration on capital mobility forms the "knowledge-capital-model” by Markusen (2002), in which both types of multinational investment activities emerge endogenously, depending on the characteristics of the home and the foreign country. Several empirical specifications have been derived in the literature from this model, which include both variables which are related to the market size of the respective economies (e.g. aggregate GDP), and variables which refer to differences in factor endowments (e.g. differences in GDP per capita or skill endowments). The findings of this literature on the impact of factor endowments are ambiguous: While the results of Carr et al. (2001) indicate that differences in factor endowments have a positive impact on capital movements, Bloningen et al. (2003) argue that the empirical model in Carr et al. (2001) is misspecified. Consequently, they find no significant impact of differences in factor endowments in their specification. Finally, Geishecker and Görg (2005) distinguish between FDI in manufacturing and non-manufacturing sectors and find for manufacturing FDI a positive impact of the difference in per capita GDP, while the aggregate impact is ambiguous. 
For the simulations carried out here we assume, following the literature, that international investments are function of the both the market size and the difference in factor endowments, i.e. that

$$
\Delta K_{f h}=a_{0}+a_{1}\left(Y_{f}+Y_{h}\right)+a_{2}\left|Y_{f}-Y_{h}\right|+a_{3}\left|y_{f}-y_{h}\right|+a_{4} D_{f h}\left|y_{f}-y_{h}\right|+\eta^{\prime} X_{f h},
$$

where $\Delta K_{f h}$ is a measure for the bilateral movement of physical capital from sending country $f$ to receiving country $h$ (e.g. FDI), $Y_{i}$ is the aggregrate GDP in country $i$ ( $i=f$, $h), y_{i}$ the GDP per capita, and $D_{f h}$ a dummy variable which has a value of one if the GDP per capita in the sending country is higher than in the receiving country, and a value of zero, if otherwise, $X_{f h}$ is a matrix of other variables such as trade volumes or trade costs, and the corresponding vector of parameters. Thus, bilateral investment from sending country $f$ in receiving country $h$ is a function of joint GDP, the difference in aggregate GDP, the difference in per capita incomes and the income of country $f$ relative to country $h$. For a motivation of this specification see Blonigen et al. (2003), Carr et al. (2001) and Geishecker and Görg (2005).

\section{Table B1 Explanation of Foreign Direct Investment}

\begin{tabular}{lrrr}
\hline \hline & coefficient & & t-statistics \\
\hline$G D P_{f}+G D P_{h}$ & 0.019 & ${ }^{* * *}$ & 30.13 \\
$\left|G D P_{f}-G D P_{h}\right|$ & -0.013 & $* * *$ & 6.61 \\
$\left|g d p_{f}-g d p_{h}\right|$ & $-257,903$ & ${ }^{* * *}$ & 3.99 \\
$D_{f} \times\left|g d p_{f}-g d p_{h}\right|$ & 170,164 & ${ }^{* * *}$ & 3.15 \\
$\left|G D P_{f-} G D P_{h}\right| \times\left|g d p_{f}-g d p_{h}\right| / 1,000,000$ & -0.105 & $* * *$ & 16.68 \\
$\left|g d p_{f}-g d p_{h}\right| \times X_{f h}$ & $-40,144$ & $*$ & 1.66 \\
$M_{f h}$ & $52,922,065$ & & 0.3 \\
$X_{f h}$ & $869,200,000$ & $*$ & 1.69 \\
Constant & $-9,032,000,000$ & $* * *$ & 8.95 \\
Observations & 6,819 & & \\
Number of country pairs & 1,227 & & \\
$\mathrm{R}^{2}$ & 0.29 & & \\
\hline
\end{tabular}

Notes: (i) The symbols ***, **, * denote levels of significance at the $1 \%-, 5 \%-$, and $10 \%-l e v e l .-$ (ii) In model (1) the $F$-test statistic for the fixed pair effects is 12.99 , which is significant at the $1 \%$ level.

(iii) The dependent variable is the stock of FDI from country $f$ in country $h . D_{f}$ denotes a dummy which has a value of one if $g d p_{f}>g d p_{h}$, and a value of zero othervise. $X_{f h}$ and and $M_{f h}$ denote exports from country $f$ to country $h$, and imports of country $f$ from country $h$, respectively.

Source: Görg and Geishecker (2005).

The parameter values used for our simulation here are taken from the estimates by Geishecker and Görg (2005), which are based on a large sample of 60 countries with 6,819 bilateral observations (see Table A5). The aggregate GDP of both countries has thus a string positive, while the dissimilarity of countries with respect to their market size has a negative impact on FDI. The coefficient for the endowment differences has a negative sign indicating the dominance of horizontal FDI. However, this does not necessarily imply that migration and FDI are complements: Since the outflow of labour 
reduces the aggregate GDP in the sending countries and, hence, increases the dissimilarities between the economies, it may also increase capital flows. Indeed, we find in our case that migration substitutes foreign investment weakly. Finally, the coefficient for interaction dummy of the rich country with the endowment difference has a positive sign, implying that capital will flow from the rich to the poor country. Note that the results of this study are similar to those of Carr et al. (2001) and Blonigen et al. (2003), although the latter models consider also other specifications and use different variables (e.g. skill variables for factor endowments). 